NBER WORKING PAPER SERIES

\title{
A THEORY OF ECONOMIC UNIONS
}

\author{
Gino Gancia \\ Giacomo A. M. Ponzetto \\ Jaume Ventura \\ Working Paper 26473 \\ http://www.nber.org/papers/w26473
NATIONAL BUREAU OF ECONOMIC RESEARCH
1050 Massachusetts Avenue
Cambridge, MA 02138
November 2019

We thank Gene Grossman, Alexander Monge-Naranjo, and participants to the CarnegieRochester-NYU Conference on Public Policy "On the Border of International Cooperation" for their useful comments. Ugur Yesilbayraktar provided excellent research assistance. We acknowledge Financial support from the Centre de Recerca en Economia Internacional (CREI), through the European Research Council (ERC), under the European Union's Horizon 2020 Programme, Grant Agreements 693512 ("Globalization, Economic Policy and Political Structure") and 714905 ("Citizens, Institutions and Globalization"), the Spanish Ministry of Economy and Competitiveness (grants RYC-2013-13838 and SEV-2015-0563), the Generalitat de Catalunya through the CERCA program, and the Leverhulme Trust through a 2019 Research Fellowship. The views expressed herein are those of the authors and do not necessarily reflect the views of the National Bureau of Economic Research.

NBER working papers are circulated for discussion and comment purposes. They have not been peer-reviewed or been subject to the review by the NBER Board of Directors that accompanies official NBER publications.

(C) 2019 by Gino Gancia, Giacomo A. M. Ponzetto, and Jaume Ventura. All rights reserved. Short sections of text, not to exceed two paragraphs, may be quoted without explicit permission provided that full credit, including $\odot$ notice, is given to the source. 
A Theory of Economic Unions

Gino Gancia, Giacomo A. M. Ponzetto, and Jaume Ventura

NBER Working Paper No. 26473

November 2019

JEL No. D71,F15,F55,F62,H77

\title{
$\underline{\text { ABSTRACT }}$
}

After decades of successful growth, economic unions have recently become the focus of heightened political controversy. We argue that this is partly due to the growth of trade between countries that are increasingly dissimilar. We develop a theoretical framework to study the effects on trade, income distribution and welfare of economic unions that differ in size and scope. Our model shows that political support for international unions can grow with their breadth and depth as long as member countries are sufficiently similar. However, differences in economic size and factor endowments can trigger disagreement over the value of unions between and within countries. The model is consistent with some salient features of the process of European integration and statistical evidence from survey data.

\author{
Gino Gancia \\ Queen Mary University of London \\ Mile End Road \\ London E1 4NS \\ United Kingdom \\ g.gancia@qmul.ac.uk \\ Giacomo A. M. Ponzetto \\ CREI, Universitat Pompeu Fabra, \\ IPEG and Barcelona GSE \\ C/ Ramon Trias Fargas, 25-27 \\ 08005 Barcelona \\ Spain \\ gponzetto@crei.cat
}

Jaume Ventura

CREI, Universitat Pompeu Fabra,

Barcelona GSE and NBER

C/ Ramon Trias Fargas, 25-27

08005 Barcelona

Spain

jventura@crei.cat 


\section{Introduction}

The development of global markets increasingly relies on international institutions providing common regulation to reduce or remove non-tariff barriers that hamper trade across national borders. The growing importance of these non-tariff barriers reflects, on the one hand, the decline of more obvious costs of international trade: progress in transportation and communication technology has steadily reduced shipping costs, while multilateral and regional trade agreements have brought tariffs down to an all-time low of $3 \%$ on average. ${ }^{1}$ On the other hand, regulatory harmonization has become more important with the increasing complexity of world trade. Recent decades have witnessed the growth of trade in tasks, with different stages of production located in different countries along global value chains. In the future, growth in international trade must increasingly lie in the service sector. Its importance is steadily growing, and it already accounts for almost two thirds of world output; yet it only accounts for less than a quarter of world trade, in part because many services - especially professional and financial services - are bound by distinct national regulations. ${ }^{2}$

The need for common policies to enable market integration and reap the gains from trade has led to the creation of international economic unions. Europe has been at the forefront of this institutional development. Establishing a common market was the core objective of the European Economic Community at its founding in 1957. Over the following six decades, what is now the European Union has grown from 6 to 28 member states, while steadily deepening economic integration and regulatory harmonization in its Single Market. Yet economic unions are far from an exclusively European phenomenon; on the contrary, they are found on every continent. ${ }^{3}$ Moreover, recent trade agreements such as the European Union-Japan Economic Partnership Agreement have increasingly emphasized regulatory cooperation, common standards and impartial enforcement procedures for the protection of

\footnotetext{
${ }^{1}$ The world average of effectively applied tariff rates, weighted by the product import shares corresponding to each partner country, was $2.59 \%$ in 2017 , as reported by the World Development Indicators.

${ }^{2}$ Over the decade to 2016 , the share of services in world value added grew from $62 \%$ to $65 \%$, as reported by the World Development Indicators. Developed countries had a similar pattern of growth (e.g., $74 \%$ to $77 \%$ for the US and $64 \%$ to $66 \%$ for the EU) and developing countries a steeper one (e.g., $43 \%$ to $52 \%$ for China). In 2016, the share of services in international trade was $23 \%$ on average, with higher figures for developed countries (e.g., $26 \%$ for the US and $29 \%$ for the EU, including intra-EU trade) and lower ones for developing countries (e.g., $16 \%$ for China).

${ }^{3}$ International economic unions, with varying levels of economic integration and institutional success, include the Caribbean Single Market (CARICOM), the Central American Common Market (SICA), and the Southern Common Market (Mercosur); the Central African Economic and Monetary Community (CEMAC) and the West African Economic and Monetary Union (UEMOA); the Eurasian Economic Union, the Gulf Cooperation Council, and the ASEAN Economic Community.
} 


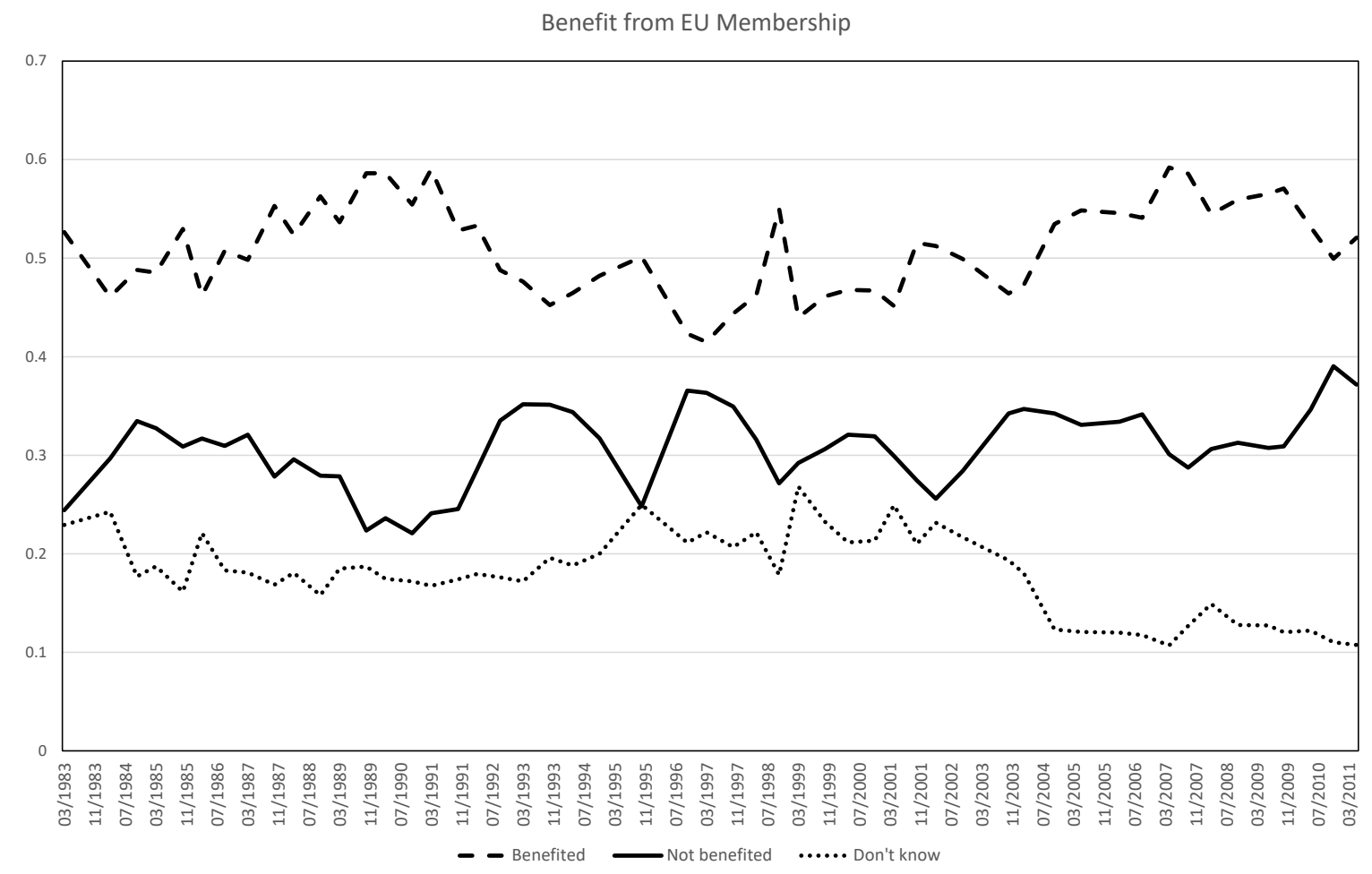

Figure 1: Perceived benefits from EU membership. Shares of responses to the question: "Taking everything into consideration, would you say that (your country) has on balance benefited or not from being a member of the European Union?" Source: Eurobarometer.

investors and intellectual-property owners.

After decades of successful growth, however, economic unions have become the focus of heightened political controversy over the past few years. After the election of President Trump in 2016, the United States abandoned both the Trans-Pacific Partnership and the Transatlantic Trade and Investment Partnership. Also in 2016, the United Kingdom voted in a referendum to leave the European Union. Euro-skepticism appears on the rise more broadly, and plans for the enlargement of the euro area are effectively on hold.

These setbacks do not mean that international institution are now facing a universal backlash, just as they did not previously enjoy universal support. Yet, they have become increasingly polarizing. Both President Trump and Brexit won narrow and bitterly divisive victories at the polls. Eurobarometer surveys show that the share of European citizens who perceive net benefits of European Union membership has remained quite steady over the decades; however, the share who perceive net costs has been gradually catching up, as the share of undecided respondents fell (Figure 1).

Preference polarization over international economic integration is naturally linked to the 
changing nature of international trade. Throughout the second half of the twentieth century, the bulk of world trade was taking place between similar countries. Likewise, economic unions initially included countries with comparable levels of income and factor endowments. A key feature of this type of economic integration is that it does not imply the reallocation of resources predicted by conventional models of trade driven by differences in factor endowments. Accordingly, one of the original motivations for developing models of trade in differentiated varieties was the need to account for episodes such as the creation of the European Economic Community, in which trade liberalization had faced little political opposition because it had led to rises in real income for owners of all factors in all member states (Helpman and Krugman 1985). Yet, the enlargements of the European Union to the East, trade liberalization in developing countries and the rise of China in global markets have brought distributional consideration to the forefront. As a result, many now fear that the negative consequences of import competition can overshadow the benefits of market size.

To shed light on these phenomena, in this paper we develop a theoretical framework to study the effects on trade, income distribution and welfare of economic unions that differ in size and scope. We then apply our model to interpret the process of European integration. Section 2 presents the basic setup of our theory. It considers a multi-country, multi-industry and multi-factor framework that combines the Krugman model of trade and monopolistic competition with the Ricardo-Viner model of specific factors. In particular, countries produce differentiated varieties in a continuum of industries employing sector-specific human capital. They differ both in size and in the distribution of their factor endowments across sectors. These differences entail potential gains from both intra-industry and inter-industry trade.

In Section 3, we add to our framework a theory of border costs. We assume that in some industries trade is possible only in the presence of union policies that overcome non-tariff barriers. For instance, common regulations or standards are often needed for firms to sell their products in foreign markets, especially in certain sectors such as financial services. We explicitly recognize that all economic unions are not the same. In particular, unions vary in their depth, i.e., the measure of industries covered by union policies; and their breadth, i.e., the set of countries included in the union. We study how these aspects of the union determine its impact on the world distribution of income and welfare.

In Section 4, we determine the sources of political support for specific economic unions and derive predictions on how this political support varies across countries, and how it reacts to changes in the depth and breadth of the union. We find that some of the effects of union policies are homogeneous within each country because they reflect changes in prices that 
accrue entirely to consumers. This is the case for the benefits of increased variety that result from intra-industry trade. Inter-industry trade also yields consumer benefits, but in addition it has distributive consequences across workers in the same country. Workers in exporting industries reap an extra gain from accessing foreign markets, while workers in importing industries lose from the entry of foreign competitors into their home market. The model paints a rich and realistic picture, which yields the following main results.

If union members are sufficiently similar, there is no disagreement either between or within countries. Support for the union unanimously increases with the size and scope of the union. The intuition for this result is simply that the value of trade-promoting policies increases with the number of potential trading partners and the industries they cover.

However, disagreement over the value of unions arises if countries differ in size, income and endowments. Differences in economic size introduce disagreement over the value of the union between countries, as the benefit from the access to the larger union market is higher for small and poor countries. Comparative advantage due to differences in relative endowments introduces instead disagreement over the union within countries. Workers in comparativeadvantage industries support the union because they stand to benefit as exporters. Workers in comparative-disadvantage industries benefit from lower prices, but experience a fall in their income due to import competition from other countries in the union. Hence, the effect of comparative advantage on the support for market integration is nuanced. On the one hand, inter-industry trade increases the value the union. On the other hand, it also generates winners and losers. Various scenarios may arise. For instance, adding dissimilar countries can weaken the support for the union, even when more market integration is beneficial for all countries as a whole. The reason is that, while winners gain more from such an enlargement, the number of sectors and workers threatened by import competition increases.

Section 5 discusses how our theory helps interpret the history of European integration. In the twentieth century, the European Union steadily grew in size up to 15 members, while constantly deepening market integration and enjoying broad political support. This pattern is consistent with our prediction that economic unions can grow without triggering opposition when their members are not too dissimilar. In the twenty-first century, however, enlargement has brought into the European Union countries that are smaller, poorer and have a different mix of factor endowments. In keeping with our theory, this has led to growing political tensions and discontent among losers in larger, richer countries. We provide new statistical evidence that measures of economic size and exposure to import competition from other European Union countries correlate with survey data on attitudes towards the union precisely 
as predicted by our model. In particular, rich and large countries tend to have a more negative image of the European Union. Moreover, support for the European Union is weaker in countries with a larger share of workers employed in comparative-disadvantage sectors; finally, this share has increased in many member countries after the 2004-06 enlargements.

Related literature There is a large literature on international and regional trade agreements: Freund and Ornelas (2010), Maggi (2014, 2016), Grossman (2016) and Bagwell and Steiger (2016) provide excellent surveys. This literature considers international agreements as coordination and commitment devices to prevent the escalation of negative externalities generated by trade policy and to protect governments from the influence of domestic pressure groups. It has studied the design of rules for achieving these goals, and the merits of multilateral relative to regional negotiations. In contrast, we study the effect of unions at eliminating non-tariff barriers to trade and removing the undesirable "border effect" that these barriers produce. Our focus is on the heterogeneous costs and benefits of these policies. We abstract from coordination and commitment problems, which have been studied extensively. A recent paper that also examines non-tariff barriers, but focuses instead on coordination problems in the adoption of product standards, is that of Grossman, McCalman and Staiger (2019).

Our paper is also related to the literature on the size of trade-promoting international unions. Several papers build on the insight from theories of federalism (Oates 1972) that unions, like centralized jurisdictions, reap the benefits of coordination and market integration, but at the cost of imposing uniform policies on members with different preferences (Bolton and Roland 1996, 1997; Alesina and Wacziarg 1999; Alesina, Spolaore and Wacziarg 2000; Casella 2001; Casella and Feinstein 2002; Alesina, Angeloni and Etro 2005; Gancia, Ponzetto and Ventura 2018). These papers have studied how the size of jurisdictions changes with exogenous changes in the costs of trade. In contrast, we study the effect of unions that vary in size and scope on countries that differ in size, productivity and factor endowments. In this respect, our model is also related to a small set of papers studying asymmetric unions (Harstad 2006; Berglof et al. 2008, 2012). This literature has however focused on a different question, namely, whether the possibility of forming "inner clubs" is desirable and/or can sustain more cooperation in the presence of externalities.

Finally, there is a new but fast-growing literature on the recent backlash against globalization. There is evidence that voters exposed to import competition become more protectionist (Feigenbaum and Hall 2015), and that the opposition of import-exposed workers to interna- 
tional economic integration was one of the economic drivers of support for Brexit (Becker, Fetzer and Novy 2017; Colantone and Stanig 2018a). More broadly, a series of recent papers have investigated empirically the connection of import competition with economic nationalism and political extremism (Che et al. 2016; Autor et al. 2017; Colantone and Stanig 2018b). Dippel, Gold and Heblich (2015) and Jensen, Quinn and Weymouth (2017) have shown that, just as import competition is positively linked to anti-establishment politics, export opportunities have the opposite political effect.

From a theoretical perspective, political opposition to globalization has been associated mostly to a rise in inequality (Grossman and Helpman 2019; Pastor and Veronesi 2019). In this paper, we also consider inequality, but we shows how it interacts with other factors giving rise to a rich set of results. Interestingly, Buera, Monge-Naranjo and Primiceri (2011) warned that, in a model with uncertainty and learning, a large economic shock could trigger a reversal against market-oriented policies. We instead abstract from issues related to information frictions. While all the papers in this literature study unilateral policy choices, we focus on political support for existing international unions.

\section{A model of international trade With Border Costs}

This section develops a multi-country, multi-industry and multi-factor framework that combines the Krugman model of trade and monopolistic competition with the Ricardo-Viner model of specific factors. Each industry contains a continuum of monopolistic competitors producing differentiated products and earning zero profits. Labor is the only factor of production; but there are many different types of labor, one for each industry.

As usual, country borders affect trade. In labor markets, border costs are prohibitive and producers hire domestic labor only. Thus, there is a local labor market for each country and labor type. In product markets, border costs vary across industries and country pairs. Thus, some product markets are local, some are global, and some are somewhere in between.

\subsection{ECONOMic ENVIRONMENT}

We consider a world with a discrete set of countries: $\mathcal{N}=\{1,2, \ldots, N\}$ with typical element $n \in \mathcal{N}$. Residents of all countries consume products from and work in a continuum of industries: $\mathcal{I}=[0,1]$ with typical element $i \in \mathcal{I}$. Producers in each industry supply a continuum of differentiated product varieties $\mathcal{Z}^{i}=\left[0, Z^{i}\right]$ with typical element $z \in \mathcal{Z}^{i}$. Workers are specialized and each industry uses a different type of worker. Within an industry/country 
pair all workers and producers are identical, and we refer to them as the "workers in $i / n$ " or the "producers in $i / n$ ".

Countries differ in terms of both their sizes and their industry productivities. We normalize the world's labor force (and population) to one and define $L_{n}^{i}$ as the share of this labor force in $i / n$, such that $L_{n}=\int_{0}^{1} L_{n}^{i} d i$ is the share of the world's population that resides in country $n$. Let $\pi_{n}^{i}$ be the productivity of workers in $i / n$. For convenience, we normalize world average industry productivities to one, i.e., $\sum_{n \in \mathcal{N}} L_{n}^{i} \pi_{n}^{i}=1$. This means that a worker in $i / n$ produces $\pi_{n}^{i}$ times the output produced by the world's average worker in industry $i$.

Industries differ in their sensitivity to borders. In particular, producers in $i / n$ supplying consumers in country $m$ must ship $b_{n m}^{i} \geq 1$ units of their product varieties to ensure that one unit arrives at destination. Naturally, there are no border costs for internal trade, i.e., $b_{n n}^{i}=1$. Thus, if we let $P_{n}^{i}(z)$ be the consumer price in country $n$ of a variety $z$ of industry $i$ produced in country $n$, arbitrage ensures that $P_{m}^{i}(z) \leq b_{n m}^{i} P_{n}^{i}(z)$ for all destination markets $m \in \mathcal{N}$.

\subsection{Preferences and COnsumption}

All workers have the same preferences. Let $C_{n}^{i, j}(z)$ be the consumption of variety $z$ of industry $j$ by a worker in $i / n$. Her preferences are described by the following nested CES utility function:

$$
W_{n}^{i}=\int_{0}^{1} \ln C_{n}^{i, j} d j \text { with } C_{n}^{i, j}=\left[\int_{0}^{Z^{i}} C_{n}^{i, j}(z)^{\frac{\sigma-1}{\sigma}} d z\right]^{\frac{\sigma}{\sigma-1}},
$$

with $\sigma>1$. This utility function treats all industries and varieties symmetrically. The elasticity of substitution between varieties of different industries is one, while the elasticity of substitution between varieties of the same industry is $\sigma$.

The budget constraint differs across workers because they face different prices and earn different wages. Let $P_{n}^{i}(z)$ be the price of variety $z$ of industry $i$ in country $n$. Let $Y_{n}^{i}$ be the wage or income of a worker in $i / n$. The budget constraint of this worker is:

$$
\int_{0}^{1} \int_{0}^{Z^{j}} P_{n}^{j}(z) C_{n}^{i, j}(z) d z d j \leq Y_{n}^{i}
$$

Note that all workers in a country face the same prices, but they do not earn the same wage if they work in different industries. 
Maximizing the utility function in Equation (1) subject to the budget constraint in Equation (2) we find the following spending shares:

$$
\frac{P_{n}^{j}(z) C_{n}^{i, j}(z)}{Y_{n}^{i}}=\frac{P_{n}^{j}(z)^{1-\sigma}}{\int_{0}^{Z^{j}} P_{n}^{j}\left(z^{\prime}\right)^{1-\sigma} d z^{\prime}}
$$

for all $z \in \mathcal{Z}^{j}$ and $j \in \mathcal{I}$. Equation (3) describes how the worker in $i / n$ distributes her spending across product varieties of different industries. Note that all workers distribute their spending uniformly across industries regardless of prices. ${ }^{4}$ This is the key simplification that we obtain by assuming a unit elasticity of substitution between varieties of different industries. The distribution of spending across varieties within a given industry is not uniform, though. Since the elasticity of substitution between varieties of the same industry is higher than one, a larger share of spending goes to cheaper varieties.

Substituting the consumptions implicit in Equation (3) into the utility function in Equation (1), we obtain the indirect utility function:

$$
W_{n}^{i}=\ln Y_{n}^{i}-\int_{0}^{1} \ln P_{n}^{j} d j
$$

where $P_{n}^{j}$ is the ideal price index of industry $j$ in country $n$ :

$$
P_{n}^{j}=\left[\int_{0}^{Z^{j}} P_{n}^{j}(z)^{1-\sigma} d z\right]^{\frac{1}{1-\sigma}}
$$

The welfare of the worker in $i / n$ depends positively on her wage and negatively on industry prices. Thus, we will focus on the effects of an economic union on wages $\left\{Y_{n}^{i}\right\}$ and prices $\left\{P_{n}^{i}\right\}$ to predict attitudes towards the union.

\subsection{Technology AND PRODUCtion}

In all industries, there is an arbitrarily large set of product varieties that can be potentially produced. In each industry/country pair, there is an arbitrarily large set of potential producers that can produce these varieties. To produce $Q_{n}^{i}(z)>0$ units of variety $z$, producers

\footnotetext{
${ }^{4}$ That is, $\int_{0}^{Z^{j}} P_{n}^{j}(z) C_{n}^{i, j}(z) d z=Y_{n}^{i}$ for all $j$.
} 
in $i / n$ need $L_{n}^{i}(z)$ units of labor as given by:

$$
L_{n}^{i}(z)=\frac{\phi+Q_{n}^{i}(z)}{\pi_{n}^{i}}
$$

where $\phi>0$ is a fixed cost that is paid only if production is positive; and recall that $\pi_{n}^{i}$ is the productivity of workers in $i / n$. This formulation of labor requirements can be interpreted as the sum of a fixed cost, i.e., $\phi / \pi_{n}^{i}$ workers are required to start producing; and a variable cost, i.e., $1 / \pi_{n}^{i}$ additional workers are required per unit of output produced. Labor productivity affects both aspects of production. Thus, productivity differences are not only industry/country specific, but also labor-augmenting.

The main results of this setup are well known: (i) active producers choose to produce differentiated products and act as monopolists in product markets; (ii) potential producers pay the fixed cost and become active until profits are eliminated. Thus, each industry contains a continuum of monopolistic competitors, each of them producing a differentiated product in a single location and earning zero profits. Since there is a single producer for each product variety, for any variety $z$ of industry $i$ produced in country $n$ we have that:

$$
P_{m}^{i}(z)=b_{n m}^{i} P_{n}^{i}(z)
$$

for all industries and origin/destination pairs. Thus, we can construct the demand schedule for any product variety by adding the demands from workers in all country/industry pairs: ${ }^{5}$

$$
P_{n}^{i}(z) Q_{n}^{i}(z)=\sum_{m \in \mathcal{N}} \frac{\left[b_{n m}^{i} P_{n}^{i}(z)\right]^{1-\sigma}}{\int_{0}^{Z^{i}} P_{m}^{i}\left(z^{\prime}\right)^{1-\sigma} d z^{\prime}} \int_{0}^{1} L_{m}^{j} Y_{m}^{j} d j
$$

Equation (8) says that sales are a declining function of price. In particular, an increase in the price of a product variety by one percent leads to a $\sigma-1$ percent decrease in sales. Sales also depend negatively on border costs, and positively on the incomes of all countries and the prices of other product varieties in the industry. These additional determinants of sales, however, are taken as given by producers.

Producers in $i / n$ maximize profits subject to the technology in Equation (6), the wage $Y_{n}^{i}$, and the demand schedule in Equation (8). Free entry ensures that there are enough active producers in $i / n$ to bring profits down to zero. These observations imply two standard

\footnotetext{
${ }^{5}$ Note that $Q_{n}^{i}(z)=\sum_{m \in \mathcal{N}} b_{n m}^{i} \int_{0}^{1} C_{m}^{j, i}(z) d j$ and then use the consumptions implicit in Equation (3).
} 
results:

$$
P_{n}^{i}=\frac{\sigma}{\sigma-1} \frac{Y_{n}^{i}}{\pi_{n}^{i}}
$$

and

$$
Q_{n}^{i}(z)=\phi(\sigma-1) .
$$

Equation (9) says that producers charge a markup over labor costs. Equation (10) says that the production of each variety is increasing in the fixed cost and the elasticity of demand.

Since each producer in $i / n$ demands the services of $\phi \sigma / \pi_{n}^{i}$ specialized workers (see Equations (6) and (10)) and there is measure $L_{n}^{i}$ of specialized workers available in the country, the measure of active producers in $i / n$ must be $L_{n}^{i} \pi_{n}^{i} /(\phi \sigma)$. Adding across countries, we find the measure of product varieties of industry $i$ produced in the world:

$$
Z^{i}=\frac{1}{\phi \sigma},
$$

where we have used the normalization $\sum_{n \in \mathcal{N}} L_{n}^{i} \pi_{n}^{i}=1$.

\subsection{Solving For INDUStry InCOMES AND PRICES}

Let us now solve for industry prices in country $n$. To determine those, it is convenient to define the supply of labor in $i / n$ and its wage in terms of efficiency units, respectively:

$$
H_{n}^{i} \equiv \lambda_{n}^{i} \pi_{n}^{i} \text { and } y_{n}^{i} \equiv \frac{Y_{n}^{i}}{\pi_{n}^{i}} .
$$

Note then that (i) the measure of product varieties produced in $i / n$ is proportional to the former: $H_{n}^{i} /(\phi \sigma)$; while (ii) the price in any country $m$ of all product varieties from $i / n$ is proportional to the latter: $y_{n}^{i} b_{n m}^{i} \sigma /(\sigma-1)$.

These observations, together with Equation (5), imply that:

$$
P_{n}^{i}=\left[\frac{1}{\Phi} \sum_{m \in \mathcal{N}} H_{m}^{i}\left(y_{m}^{i} b_{m n}^{i}\right)^{1-\sigma}\right]^{\frac{1}{1-\sigma}},
$$

where $\Phi \equiv \phi \sigma^{\sigma}(\sigma-1)^{1-\sigma}$ to simplify notation. Equation (13) describes the ideal price index of industry $i$ for residents of country $n$. This price index displays the benefits of forward linkages that increase with access to import markets. It is increasing with border costs $b_{m n}^{i}$, especially those that hinder importing from countries with a large and productive labor force 
in the industry $H_{m}^{i}$ - since these countries produce a larger measure of varieties - and from countries with low wages per efficiency unit of labor in the industry $y_{m}^{i}$ - since these countries sell their products at a lower price.

Let us next solve for wages in $i / n$. Since producers earn zero profits all the sales revenues earned by producers in $i / n$ accrue to workers in $i / n$. To find those, we simply note that the spending of country $m$ on products of country $n$ is given by:

$$
\frac{1}{\Phi} H_{n}^{i}\left(\frac{y_{n}^{i} b_{n m}^{i}}{P_{m}^{i}}\right)^{1-\sigma} \int_{0}^{1} H_{m}^{j} y_{m}^{j} d j
$$

This expression is the product of three terms: (i) the measure of varieties produced by the workers in $i / n$; (ii) the share of spending on each of these varieties by workers in country $m$; and (iii) the combined income of all workers in country $m$. Thus, the product of these terms gives us the sales in country $m$ of producers in $i / n$. Adding these sales across all countries, we find the income of workers in $i / n$ :

$$
y_{n}^{i}=\left[\frac{1}{\Phi} \sum_{m \in \mathcal{N}}\left(\frac{P_{m}^{i}}{b_{n m}^{i}}\right)^{\sigma-1} \int_{0}^{1} H_{m}^{j} y_{m}^{j} d j\right]^{\frac{1}{\sigma}} .
$$

Equation (15) describes the wage per efficiency unit of workers in $i / n$. This nominal wage displays the benefits of backward linkages that increase with access to export markets. It is decreasing with border costs $b_{n m}^{i}$, especially those that hinder exporting to large and productive countries - since these countries generate greater demand $\left(\int_{0}^{1} H_{m}^{j} y_{m}^{j} d j\right)$-and countries with high price indices $P_{m}^{i}$ - since exports face weaker competition in those markets.

Equations (13) and (15) can be solved for the matrix of equilibrium industry prices $\left\{P_{n}^{i}\right\}$ and incomes $\left\{y_{n}^{i}\right\}$ as a function of border costs, up to a choice of numeraire. We use world income as the numeraire and set $\sum_{n \in \mathcal{N}} \int_{0}^{1} H_{n}^{i} y_{n}^{i} d i=1$ from now on. Thus, all incomes can be interpreted as shares of world income. Our focus is on border costs $\left\{b_{m n}^{i}\right\}$, which are not exogenous: we turn to them now.

\section{Modeling an ECONOMic Union}

What determines the matrix of bilateral border costs? How does an economic union affect this matrix? We now add to our framework a theory of border costs and the impact of an economic union on them. This theory recognizes that all economic unions are not the same. In particular, unions vary in their depth, i.e., the measure of industries covered; and their 
breadth, i.e., the set of countries included. We study how these features of the union affect the distribution of industry incomes and prices.

\subsection{A STYLIZED THEORY OF BORDER COSTS}

There is a share of industries that are insensitive to borders. In particular, assume that border costs for products varieties of these industries are negligible. We assign low indices to these industries:

$$
\text { if } i \in[0, \tau] \text {, then } b_{n m}^{i}=1 \text { for all } n, m \in \mathcal{N} \text {. }
$$

The rest of the industries are sensitive to border costs. In particular, assume these costs are prohibitive unless an economic union removes them. An economic union (or union, for brevity) is defined by the measure of industries covered: $t \in[0,1-\tau]$; and the set of member countries: $\mathcal{U} \subseteq \mathcal{N}$. These two features jointly determine its effects on border costs:

$$
\text { if } i \in[\tau, 1), \text { then } b_{n m}^{i}= \begin{cases}1 & \text { if } n=m \text { or } i \in(\tau, \tau+t] \text { and } n, m \in \mathcal{U} \\ \infty & \text { otherwise. }\end{cases}
$$

That is, the union removes border costs between its members (i.e., $n \in \mathcal{U}$ ) for the measure of industries covered (i.e., $i \in(\tau, \tau+t])$. Inside the union, these industries enjoy a single common market. Outside the union, these industries are local.

There are thus three types of industries: (i) those with global markets: $i \in[0, \tau]$; (ii) those with local markets: $i \in(\tau+t, 1]$ for $n \in \mathcal{U}$ and $i \in(\tau, 1]$ for $n \notin \mathcal{U}$; and (iii) those with a union market: $i \in(\tau, \tau+t]$ for $n \in \mathcal{U}$. We shall use this simple model in what follows, and focus on the effects of $t$ and $\mathcal{U}$.

For later reference, we denote the aggregate factor endowment of the union in industry $i$ by $H_{U}^{i} \equiv \sum_{n \in \mathcal{U}} H_{n}^{i}$.

\subsection{INDUSTRY INCOMES AND PRICES WITH AN ECONOMIC UNION}

We derive now industry incomes and prices for a given economic union with membership $\mathcal{U}$ and industry coverage $t$. The first observation is that spending is uniformly distributed across industries. This is a direct implication of assuming a unit elasticity of substitution between varieties of different industries. Thus, each industry receives an income equal to one (recall that world income has been normalized to one), and we only need to determine how this income is distributed within industries. 
In global industries, border costs are negligible and the prices of all product varieties are equalized. Thus, in these industries factor prices are also equalized in terms of efficiency units. Since we have normalized the world's factor endowment in each industry to 1 :

$$
y_{n}^{i}=1 \text { if } i \in[0, \tau] .
$$

Equation (18) implies that the share of industry income that goes to any individual worker is her share of world output in the industry. Hence, workers' incomes equal their productivities: $Y_{n}^{i}=\pi_{n}^{i}$.

In local industries, border costs are prohibitive and countries consume only the product varieties produced within the country. Since spending is uniformly distributed across varieties, factor incomes are determined by local factor scarcity:

$$
y_{n}^{i}=\frac{1}{H_{n}^{i}} \int_{0}^{1} H_{n}^{j} y_{n}^{j} d j \text { if either } i \in(\tau+t, 1] \text { and } n \in \mathcal{U} \text { or } i \in(\tau, 1] \text { and } n \notin \mathcal{U} \text {. }
$$

Equation (19) simply reflects the fact that the aggregate spending on industry $i / n\left(H_{n}^{i} y_{n}^{i}\right)$ equals the average spending or income in country $n\left(\int_{0}^{1} H_{n}^{j} y_{n}^{j} d j\right)$.

In union industries, the situation is a bit more complex. Border costs are prohibitive outside the union and, as a result, union members only consume product varieties produced within the union. Border costs are negligible inside the union, though, so that the prices of all union product varieties are equalized. As a consequence, factor prices are also equalized within the union:

$$
y_{n}^{i}=\frac{1}{H_{U}^{i}} \sum_{m \in \mathcal{U}} \int_{0}^{1} H_{m}^{j} y_{m}^{j} d j \text { if } i \in(\tau, \tau+t] \text { and } n \in \mathcal{U} .
$$

Equation (20) is the direct equivalent of Equation (19) when the market is the union instead of the country. Unionwide spending on industry $i\left(H_{U}^{i} y_{n}^{i}\right)$ equals average income in the union $\left(\sum_{m \in \mathcal{U}} \int_{0}^{1} H_{m}^{j} y_{m}^{j} d j\right)$.

Equations (18) and (19) suffice to characterize equilibrium factor rewards in all countries that do not belong to the union. Equation (20) completes the characterization for union members. We can now use these equations to determine equilibrium incomes in every 
country-industry $i / n$ :

$$
Y_{n}^{i}= \begin{cases}\pi_{n}^{i} & \text { if } i \in[0, \tau] \\ \frac{Y_{U}}{H_{U}^{i}} \pi_{n}^{i} & \text { if } i \in(\tau, \tau+t] \text { and } n \in \mathcal{U} \\ \frac{Y_{n}}{H_{n}^{i}} \pi_{n}^{i} & \text { otherwise, }\end{cases}
$$

where $Y_{n} \equiv \int_{0}^{1} H_{n}^{i} y_{n}^{i} d i$ is country $n$ 's nominal income (i.e., its share of the world's nominal income) and $Y_{U} \equiv \sum_{n \in \mathcal{U}} \int_{0}^{1} H_{n}^{i} y_{n}^{i} d i$ is the union's nominal income. In equilibrium, these can be expressed explicitly as:

$$
Y_{U}=\frac{1}{\tau} \int_{0}^{\tau} H_{U}^{i} d i
$$

and

$$
Y_{n}= \begin{cases}\frac{1}{\tau} \int_{0}^{\tau} H_{n}^{i} d i & \text { if } n \notin \mathcal{U} \\ \frac{1}{\tau+t}\left(\int_{0}^{\tau} H_{n}^{i} d i+Y_{U} \int_{\tau}^{\tau+t} \frac{H_{n}^{i}}{H_{U}^{i}} d i\right) & \text { if } n \in \mathcal{U} .\end{cases}
$$

Equations (21), (22) and (23) show how income is distributed across industry/country pairs. The design of the union, i.e., $t$ and $\mathcal{U}$, determines the set of union industries and how income is distributed within this set of industries.

In global industries, incomes reflect productivities. In local industries, factors are expensive in countries where they are scarce relative to the country's aggregate income. In union industries, factors are expensive in industries whose union-wide endowment is scarce relative to the union's aggregate income. Aggregate incomes reflect productivities in all tradable industries. For countries that do not belong to the union, and for the union as a whole, nominal income simply equals the average factor endowment in effective units across all global industries. For union members, nominal income can be intuitively decomposed as a weighted average of the country's income in global industries and the country's share of the union's income in union industries.

These results allow us to compute industry prices as follows:

$$
P_{n}^{i}= \begin{cases}\Phi^{\frac{1}{\sigma-1}} & \text { if } i \in[0, \tau] \\ \Phi^{\frac{1}{\sigma-1}}\left(H_{U}^{i}\right)^{-\frac{1}{\sigma-1}} \frac{Y_{U}}{H_{U}^{i}} & \text { if } i \in(\tau, \tau+t] \text { and } n \in \mathcal{U} \\ \Phi^{\frac{1}{\sigma-1}}\left(H_{n}^{i}\right)^{-\frac{1}{\sigma-1}} \frac{Y_{n}}{H_{n}^{i}} & \text { otherwise. }\end{cases}
$$

To interpret Equation (24), recall that prices are low in the industries that offer many 
varieties at a low price per variety. Global industries offer many varieties at a uniform average price. Union industries offer less variety $\left(H_{U}^{i}<1\right)$ at a price that reflects the unionwide relative scarcity of each industry relative to the average global industry $\left(Y_{U} / H_{U}^{i}\right)$. Local industries offer even less variety $\left(H_{n}^{i}<H_{U}^{i}\right)$ at a price that reflects the local scarcity of a non-tradable industry relative to the average tradable industry $\left(Y_{n} / H_{n}^{i}\right)$. Naturally, nontradables are expensive if their supply is scarce because the country has limited resources to produce them, while demand is plentiful because the country is good at producing tradables. The intuitions are thus clear: consumers care about both product variety and product prices, and the design of the union affects both.

\section{The Distribution of Gains AND LOSSES FROM THE UNion}

We are now ready to derive predictions about the political support for the union. To do this, we ask the inhabitants of our theoretical world whether a specific union raises their welfare relative to having no union at all. We then record their positive answers as support for the union, and the negative ones as opposition to the union. Thus, our exercise consists of counting winners and losers.

\subsection{The GAINS FROM UNION MEMBERShIP}

Let $W_{n}^{i}(t, \mathcal{U})$ be the welfare of workers in $i / n$ with a union that covers a measure $t$ of industries and a set $\mathcal{U}$ of countries. Then, we define $\Delta W_{n}^{i}(t, \mathcal{U})$ as the change in welfare that the union generates relative to a scenario without the union:

$$
\Delta W_{n}^{i}(t, \mathcal{U}) \equiv W_{n}^{i}(t, \mathcal{U})-W_{n}^{i}(0, \emptyset)
$$

We say that workers in $i / n$ support the union if $\Delta W_{n}^{i}(t, \mathcal{U})>0$ and oppose it if $\Delta W_{n}^{i}(t, \mathcal{U})<$ 0 . If the union has no effect on welfare, we say that workers in $i / n$ are indifferent about the union.

We start with the following observation:

$$
\Delta W_{n}^{i}(t, \mathcal{U})=\Delta \ln Y_{n}(t, \mathcal{U})-\int_{0}^{1} \Delta \ln P_{n}^{j}(t, \mathcal{U}) d j+\Delta \ln \frac{Y_{n}^{i}(t, \mathcal{U})}{Y_{n}(t, \mathcal{U})}
$$

where $\Delta \ln Y_{n}(t, \mathcal{U}), \Delta \ln P_{n}^{j}(t, \mathcal{U})$ and $\Delta \ln Y_{n}^{i}(t, \mathcal{U})$ are defined analogously as differences relative to a scenario without the union. Equation (26) breaks down the effects of the union 
for the worker in $i / n$ into two components: (i) the welfare gains for an artificial representative worker of country $n$ (the first two terms in Equation (26)); plus (ii) a redistribution that affects the worker in $i / n$ (the third term in Equation (26)).

We can interpret the first component as the welfare gains of a policy package that includes both union membership and a redistributive policy that keeps the domestic income distribution unchanged. Such a policy is implemented with the following set of transfers:

$$
X_{n}^{i}(t, \mathcal{U})=\frac{Y_{n}^{i}(0, \emptyset)}{Y_{n}(0, \emptyset)} Y_{n}(t, \mathcal{U})-Y_{n}^{i}(t, \mathcal{U})
$$

This policy is self-financed, i.e., $\int_{0}^{1} X_{n}^{i}(t, \mathcal{U}) d i=0$, and it implies that the gains from union membership are equally shared by all workers in country $n$. Thus, if asked whether country $n$ should adopt a policy package that includes both union membership and the redistributive policy, all workers in $n$ would give the same answer. If asked instead whether country $n$ should become a member of the union without any redistributive policy, disagreement arises as shown in Equation (26).

Naturally, this second case of unequal sharing is the empirically relevant one. But we start analyzing the case of equal sharing because it is easier analytically, and because it is a first step towards analyzing the case of unequal sharing.

\subsection{Union Membership With EQUal Sharing of Gains}

With equal sharing of the gains from union membership, all workers in $n$ experience an identical change in welfare. Moreover, this change in welfare is always non-negative and it can be decomposed into two non-negative components:

$$
\Delta \ln Y_{n}(t, \mathcal{U})-\int_{0}^{1} \Delta \ln P_{n}^{i}(t, \mathcal{U}) d i=G_{n}^{\mathrm{Intra}}(t, \mathcal{U})+G_{n}^{\text {Inter }}(t, \mathcal{U}) \geq 0
$$

where

$$
G_{n}^{\mathrm{Intra}}(t, \mathcal{U})=\frac{1}{\sigma-1} \int_{\tau}^{\tau+t} \ln \frac{H_{U}^{i}}{H_{n}^{i}} d i \geq 0
$$

and

$$
\begin{aligned}
G_{n}^{\text {Inter }}(t, \mathcal{U})=(\tau+t) \ln \left[\frac { 1 } { \tau + t } \left(\tau \frac{\int_{0}^{\tau} H_{n}^{i} d i}{\int_{0}^{\tau} H_{U}^{i} d i}+\int_{\tau}^{\tau+t}\right.\right. & \left.\left.\frac{H_{n}^{i}}{H_{U}^{i}} d i\right)\right] \\
& -\tau \ln \frac{\int_{0}^{\tau} H_{n}^{i} d i}{\int_{0}^{\tau} H_{U}^{i} d i}-\int_{\tau}^{\tau+t} \ln \frac{H_{n}^{i}}{H_{U}^{i}} d i \geq 0
\end{aligned}
$$


These components measure, respectively, the gains from intra- and inter-industry trade enabled by union membership. To be clear, even without union membership country $n$ enjoys the benefits of intra- and inter-industry trade in global industries. The terms $G_{n}^{\text {Intra }}(t, \mathcal{U})$ and $G_{n}^{\text {Inter }}(t, \mathcal{U})$ measure only the increase in the gains from trade that results from union membership, and not the total gains from trade.

The first term, $G_{n}^{\text {Intra }}(t, \mathcal{U})$, captures the gains from intra-industry trade in union industries. Consumers reduce their consumption of local varieties in favor of newly available product varieties from other union members. The second term, $G_{n}^{\text {Inter }}(t, \mathcal{U})$, measures the gains from inter-industry trade in both union and global industries. The union market allows countries to run surpluses in union industries in which they have a comparative advantage; and to run deficits in union industries in which they have a comparative disadvantage. In addition, there are also gains from trade across the two sets of global and union industries. Depending on its pattern of comparative advantage, a country could run a net trade surplus (or deficit) with the union across all union industries, and compensate it with increased imports (or exports) in global industries.

This decomposition highlights a few results that apply to our setting, some of which are familiar from trade theory.

1. The representative worker's gains from union membership increase with the size of the union's economy, and decrease with the size of the country's. Multiplying all the endowments $H_{U}^{i}$ of the union by a factor larger than one raises $G_{n}^{\text {Intra }}(t, \mathcal{U})$, while it does not affect $G_{n}^{\text {Inter }}(t, \mathcal{U})$. Hence, the benefit of union membership increases with union size. Consider two countries $n$ and $m$ such that $H_{n}^{i}$ is obtained by multiplying $H_{m}^{i}$ by a factor larger than one. Then, $G_{n}^{\text {Intra }}(t, \mathcal{U})<G_{m}^{\text {Intra }}(t, \mathcal{U})$ and $G_{n}^{\text {Inter }}(t, \mathcal{U})=G_{m}^{\text {Inter }}(t, \mathcal{U})$. Hence, the benefit of union membership declines with country size. These effects of size work entirely through intra-industry trade. Larger unions provide greater variety in the union market, which is especially valuable for small countries that have less variety in their domestic market.

2. The representative worker's gains from union membership are increasing with differences between the country's and the union's distribution of factor endowments across union industries. Consider two countries $n$ and $m$ such that, in union industries, $\left\{H_{n}^{i} / H_{U}^{i}\right\}_{i \in[\tau, \tau+t]}$ is obtained as a mean-preserving spread of $\left\{H_{m}^{i} / H_{U}^{i}\right\}_{i \in[\tau, \tau+t]}$. Then, $G_{n}^{\text {Intra }}(t, \mathcal{U})>G_{m}^{\text {Intra }}(t, \mathcal{U})$ and $G_{n}^{\text {Inter }}(t, \mathcal{U})>G_{m}^{\text {Inter }}(t, \mathcal{U})$. These effects of specialization work both through intra- and inter-indutry trade. If country $n$ is highly specialized 
in a subset of union industries, it gains a lot from the ability to export in those industries, and import instead in other union industries. In comparative-disadvantage industries it reaps consumer gains through both greater variety and lower price per variety.

3. The representative worker's gains from union membership are independent of differences between the country's and the world's distribution of factor endowments across global industries. Consider two countries $n$ and $m$ such that, in global industries, $\left\{H_{n}^{i}\right\}_{i \in[0, \tau]}$ is obtained as a mean-preserving spread of $\left\{H_{m}^{i}\right\}_{i \in[0, \tau]} \cdot{ }^{6}$ Then, $G_{n}^{\text {Intra }}(t, \mathcal{U})=G_{m}^{\text {Intra }}(t, \mathcal{U})$ and $G_{n}^{\text {Inter }}(t, \mathcal{U})=G_{m}^{\text {Inter }}(t, \mathcal{U})$. Of course, specialization across global industries also creates intra- and inter-industry gains from trade, and those are larger in country $n$ than in country $m$. However these gains are not contingent on union membership and, as a result, they do no affect the value of the union.

4. The representative worker's gains from union membership exhibit a $U$-shaped pattern in the average size of the country's global industries. Moreover, the global minimum is reached when the average income of global industries equals the average income of union industries. Consider two countries $n$ and $m$ with identical endowments in union industries: $H_{n}^{i}=H_{m}^{i}$ for $i \in(\tau, \tau+t]$. If each country's average income in global industries is less than their common average income in union industries, then the country with the lowest average income in global industries has greater gains from union membership:

$$
\text { if } \begin{aligned}
\frac{1}{\tau} \int_{0}^{\tau} H_{n}^{i} d i< & \frac{1}{\tau} \int_{0}^{\tau} H_{m}^{i} d i \leq \frac{1}{\tau} \int_{0}^{\tau} H_{U}^{i} d i \frac{1}{t} \int_{\tau}^{\tau+t} \frac{H_{n}^{i}}{H_{U}^{i}} d i \\
& \text { then } G_{n}^{\text {Intra }}(t, \mathcal{U})=G_{m}^{\text {Intra }}(t, \mathcal{U}) \text { and } G_{n}^{\text {Inter }}(t, \mathcal{U})>G_{m}^{\text {Inter }}(t, \mathcal{U}) .
\end{aligned}
$$

If each country's average income in global industries is more than their common average income in union industries, then the country with the greatest average income in global industries has greater gains from union membership:

$$
\text { if } \begin{aligned}
\frac{1}{\tau} \int_{0}^{\tau} H_{n}^{i} d i> & \frac{1}{\tau} \int_{0}^{\tau} H_{m}^{i} d i>\frac{1}{\tau} \int_{0}^{\tau} H_{U}^{i} d i \frac{1}{t} \int_{\tau}^{\tau+t} \frac{H_{n}^{i}}{H_{U}^{i}} d i \\
& \text { then } G_{n}^{\text {Intra }}(t, \mathcal{U})=G_{m}^{\text {Intra }}(t, \mathcal{U}) \text { and } G_{n}^{\text {Inter }}(t, \mathcal{U})>G_{m}^{\text {Inter }}(t, \mathcal{U}) .
\end{aligned}
$$

\footnotetext{
${ }^{6}$ Recall that the world has a unit endowment in each industry. Thus, $H_{n}^{i}$ and $H_{m}^{i}$ are the shares of the world endowment of workers in industry $i$ in country $n$ and $m$, respectively.
} 
These effects of specialization work entirely through inter-industry trade. If a country's average endowment in global industries is more different from its average endowment in union industries, union membership enables the country to have unbalanced trade across union industries as a whole, and to compensate this imbalance with trade in global industries. ${ }^{7}$

5. A similar result for the average size of the country's union industries involves some ambiguity. On the one hand, gains from inter-industry trade increase as the average income of the country's union industries diverges from the average income of global industries: this is exactly the effect discussed in the previous point. On the other hand, however, gains from intra-industry trade decrease as the average size of the country's union industries increases. Overall, the representative worker's gains from union membership may exhibit either a $U$-shaped or a $L$-shaped pattern in the average size of the country's global industries. Consider two countries $n$ and $m$ whose endowments are identical in global industries and equiproportional in union industries: $H_{n}^{i}=H_{m}^{i}$ for $i \in[0, \tau]$ and $H_{n}^{i}=\kappa H_{m}^{i}$ for $i \in(\tau, \tau+t]$ for some $\kappa>0$. If each country's average income in union industries is less than their common average income in global industries, then the country with the lowest average income in union industries has greater gains from union membership:

$$
\begin{aligned}
\text { if } \kappa<1 \text { and } \frac{1}{t} \int_{\tau}^{\tau+t} \frac{H_{m}^{i}}{H_{U}^{i}} d i \frac{1}{\tau} \int_{0}^{\tau} H_{U}^{i} d i \leq \frac{1}{\tau} \int_{0}^{\tau} H_{n}^{i} d i \\
\text { then } G_{n}^{\text {Intra }}(t, \mathcal{U})>G_{m}^{\text {Intra }}(t, \mathcal{U}) \text { and } G_{n}^{\text {Inter }}(t, \mathcal{U})>G_{m}^{\text {Inter }}(t, \mathcal{U}) .
\end{aligned}
$$

If each country's average income in union industries is more than their common average income in global industries, then their gains from union membership are unambiguously ranked in general:

$$
\begin{aligned}
\text { if } \kappa>1 \text { and } \frac{1}{t} \int_{\tau}^{\tau+t} \frac{H_{m}^{i}}{H_{U}^{i}} d i \frac{1}{\tau} \int_{0}^{\tau} H_{U}^{i} d i \geq \frac{1}{\tau} \int_{0}^{\tau} H_{n}^{i} d i \\
\text { then } G_{n}^{\text {Intra }}(t, \mathcal{U})<G_{m}^{\text {Intra }}(t, \mathcal{U}) \text { and } G_{n}^{\text {Inter }}(t, \mathcal{U})>G_{m}^{\text {Inter }}(t, \mathcal{U}) ;
\end{aligned}
$$

if $\sigma-1 \leq t / \tau$, however, gains from intra-industry trade dominate and $n$ unambigu-

\footnotetext{
${ }^{7}$ To establish these results, suppose country $n$ 's endowment in global industries $\left\{H_{n}^{i}\right\}_{i \in[0, \tau]}$ is scaled by a factor $\Gamma>0$. Then, all else equal, $\partial G_{n}^{\text {Intra }} / \partial \Gamma=0$ while $\partial G_{n}^{\text {Inter }} / \partial \Gamma=\tau t(\Gamma-\check{\Gamma}) /[(\tau \Gamma+t \check{\Gamma}) \Gamma]$ for a unique minimizer $\check{\Gamma} \equiv(1 / t) \int_{\tau}^{\tau+t}\left(H_{n}^{i} / H_{U}^{i}\right) d i \int_{0}^{\tau} H_{U}^{i} d i / \int_{0}^{\tau} H_{n}^{i} d i$.
} 
ously has lower gains from union membership than $m: G_{n}^{\text {Intra }}(t, \mathcal{U})+G_{n}^{\text {Inter }}(t, \mathcal{U})<$ $G_{m}^{\text {Intra }}(t, \mathcal{U})+G_{m}^{\text {Inter }}(t, \mathcal{U}) .^{8}$

The analysis so far has assumed that union membership is accompanied by a redistributive policy that ensures that the gains from union membership are equally shared. This assumption allowed us to focus on the representative worker of country $n$. In the absence of redistributive policies, the gains from union membership are not equally shared. In particular, union membership also disrupts the domestic income distribution in every member country, so much so that it may leave some residents worse off. We turn now to these distributive tensions.

\subsection{UNION MEMBERSHIP WITH UNEQUAL SHARING OF GAINS}

Union membership creates redistribution among workers in different industries. Equations (21), (22) and (23) immediately imply the following changes in workers' shares of national income:

$$
\Delta \ln \frac{Y_{n}^{i}(t, \mathcal{U})}{Y_{n}(t, \mathcal{U})}= \begin{cases}\ln \frac{\int_{0}^{\tau} H_{n}^{i} d i}{\int_{0}^{\tau} H_{U}^{i} d i}-\ln \left[\frac{1}{\tau+t}\left(\tau \frac{\int_{0}^{\tau} H_{n}^{i} d i}{\int_{0}^{\tau} H_{U}^{i} d i}+\int_{\tau}^{\tau+t} \frac{H_{n}^{i}}{H_{U}^{i}} d i\right)\right] & \text { if } i \in[0, \tau] \\ \ln \frac{H_{n}^{i}}{H_{U}^{i}}-\ln \left[\frac{1}{\tau+t}\left(\tau \frac{\int_{0}^{\tau} H_{n}^{i} d i}{\int_{0}^{\tau} H_{U}^{i} d i}+\int_{\tau}^{\tau+t} \frac{H_{n}^{i}}{H_{U}^{i}} d i\right)\right] & \text { if } i \in(\tau, \tau+t] \\ 0 & \text { if } i \in(\tau+t, 1] .\end{cases}
$$

The share of world income accruing to global industries does not change with union membership, but country n's share of world income does change. Thus, the log change in the share of national' income of workers in all global industries equals the opposite of the country's change in income:

$$
\Delta \ln \frac{Y_{n}^{i}(t, \mathcal{U})}{Y_{n}(t, \mathcal{U})}=\ln \frac{Y_{n}(0, \emptyset)}{Y_{n}(t, \mathcal{U})} \text { if } i \in[0, \tau]
$$

Without union membership, both union and local industries have the country's average income: $Y_{n}^{i}(0, \emptyset) / Y_{n}(0, \emptyset)=1$ if $i \in(\tau, 1]$. Local industries still do with union membership,

\footnotetext{
${ }^{8}$ To establish these results, suppose country $n$ 's endowment in union industries $\left\{H_{n}^{i}\right\}_{i \in[\tau, \tau+t]}$ is scaled by a factor $\Upsilon>0$. Then, all else equal, $\partial G_{n}^{\text {Intra }} / \partial \Upsilon=-t /[(\sigma-1) \Upsilon]<0$ while $\partial G_{n}^{\text {Inter }} / \partial \Upsilon=$ $\tau t(\Upsilon-\check{\Upsilon}) /[(\tau \check{\Upsilon}+t \Upsilon) \Upsilon]$ for a unique minimizer $\check{\Upsilon} \equiv 1 / \check{\Gamma}$. Overall, $\partial\left(G_{n}^{\text {Intra }}+G_{n}^{\text {Inter }}\right) / \partial \Upsilon=$ $t\{[(\sigma-1) \tau-t] \Upsilon-\sigma \tau \check{\Upsilon}\} /[(\sigma-1)(\tau \check{\Upsilon}+t \Upsilon) \Upsilon]$, which is monotone decreasing for $\sigma-1 \leq t / \tau$ and otherwise has a unique minimum at $\check{\Upsilon} \sigma /(\sigma-1-t / \tau)>\check{\Upsilon}$.
} 
so their share of national income is unchanged. For each union industry, instead, the log change in its share of the country's nominal income is equal to its log share with union membership:

$$
\Delta \ln \frac{Y_{n}^{i}(t, \mathcal{U})}{Y_{n}(t, \mathcal{U})}=\ln \frac{Y_{n}^{i}(t, \mathcal{U})}{Y_{n}(t, \mathcal{U})} \text { if } i \in(\tau, \tau+t] .
$$

Additional intuition about these changes in the domestic income distribution can be obtained if we focus on the changes in industry trade balances generated by union membership. Consider first union industries. For each of these industries, its share of the country's nominal income equals:

$$
\frac{Y_{n}^{i}(t, \mathcal{U})}{Y_{n}(t, \mathcal{U})}=1+\frac{T_{n}^{i}(t, \mathcal{U})}{Y_{n}(t, \mathcal{U})} \text { if } i \in(\tau, \tau+t]
$$

where $T_{n}^{i}$ denotes country $n$ 's net exports in industry $i .^{9} \quad$ Export industries gain income relative to the representative worker. These industries experience a terms of trade improvement that raises wages and their share of national income. Import industries, however, lose income relative to the representative worker. These industries experience a terms of trade worsening that lowers wages and their share of national income.

Consider next global industries. Without union membership, some of these industries have a trade surplus, and therefore their income is above the country's average. Other industries have a trade deficit and therefore their income is below the country's average. On average, however, the set of global industries have a zero trade balance. Union membership does not affect within-industry variation in trade balances. But it does affect the average trade balance, and therefore it affects all global industries in the same way. In particular, the change in the domestic income share of any global industry is driven by:

$$
\frac{Y_{n}(0, \emptyset)}{Y_{n}(t, \mathcal{U})}=1-\frac{1}{\tau} \frac{\int_{\tau}^{\tau+t} T_{n}^{i}(t, \mathcal{U}) d i}{Y_{n}(t, \mathcal{U})}
$$

Since overall trade must remain balanced, the change in the trade surplus (or deficit) in each global industry equals the total trade deficit of union industries divided by the mass of global industries. If union industries as a whole are net exporters, all global industries must reduce their net exports or increase their net imports, so they become net importers on average and suffer a terms of trade worsening that lowers their share of national income.

\footnotetext{
${ }^{9}$ In each union industry $i \in(\tau, \tau+t]$, a member $n$ has net exports to the union $T_{n U}^{i}=Y_{U} H_{n}^{i} / H_{U}^{i}-Y_{n}$. The relationship between net exports and income redistribution from union membership then follows from Equations (21) and (23).
} 
If instead union industries as a whole are net importers, all global industries must increase their net exports or reduce their net imports, so they become net exporters on average and enjoy a terms of trade improvement that raises their share of national income.

Naturally, the trade balance in local industries is zero both without and with union membership. As a result, local industries do not experience a change in the share of national income.

These results suggest that workers in all local industries and all exporting union industries support union membership. Whether workers in global industries and workers in importing union industries support union membership is ambiguous. But we can still say a few things about them. Workers in importing union industries are divided. Those with a weak comparative disadvantage still support the union since it lowers the cost of living. Those with a strong comparative disadvantage do not support the union. All workers in global industries are affected in the same way. Thus, all global industries support union membership if, as a group, they have a comparative advantage relative to union industries. Otherwise, they may or may not support union membership. They will support it because of its consumer benefits if the average comparative disadvantage of global industries relative to union industries is weak. They will oppose the union because of producer losses if their average comparative disadvantage is strong.

Finally, it is worth saying a bit more about the redistribution caused by the union. In a sense, all our simplifying assumptions have been designed to "manage" the shape of this redistribution so as to obtain a clear theoretical benchmark. For instance, there is no redistribution between tradable (global and union) and non-tradable (local) industries. The reason, of course, is the unit elasticity of substitution between products of different industries. If this elasticity were larger than one, there would also be a redistribution from non-tradable industries to tradable ones. If this elasticity were less than one, this redistribution would go in the opposite direction.

There is no redistribution either from non-members of the union to members of the union or vice versa. Even if we kept the unit elasticity assumption, we would observe such redistribution if border costs were not extreme. Since the union lowers the cost of trading among its members, it shifts demand towards union members and away from non-members. We do not observe this shift of demand away from non-members because there is no such demand with extreme border costs. If we made these costs less extreme, the creation of a union would lead to redistribution from non-members to members within the affected industries. 
All these complications might be important in quantitative applications. However, they seem likely to be less central than the already rich pattern of redistribution we focus upon here. In any case, even these additional redistributive patterns become clearer once we look at them from the perspective of our stylized benchmark.

\section{Application: European integration and its discontents}

European integration started when 6 countries-Belgium, France, Italy, Luxembourg, the Netherlands, and West Germany - signed the Treaty of Paris in 1952 and the Treaty of Rome in 1957, creating the European Economic Community. Member countries removed custom duties and agreed on a common agricultural policy. The first enlargement happened in 1973, when Denmark, Ireland and the United Kingdom joined the union. During the 1970s, the union implemented regional policies to help the development of poorer areas and adopted laws to protect the environment. Over time, the European Parliament increased its influence and, from 1979, all citizens started to elect its members directly. In 1981, Greece joined the union. Spain and Portugal followed in 1986. In the same year, the Single European Act extended Community powers especially in the area foreign policy. In 1993, the Maastricht Treaty established the European Union and the Single Market with its "four pillars:" the free movement of goods, services, capital and persons. In 1995, the European Union gained three more new members: Austria, Finland and Sweden.

In 1999, the euro as a currency was launched. Ten new countries - Cyprus, the Czech Republic, Estonia, Hungary, Latvia, Lithuania, Malta, Poland, Slovakia and Slovenia-joined the European Union in 2004, followed by Bulgaria and Romania in 2007. In response to the eurozone debt crisis, the so-called "banking union" was established, transferring responsibilities for banking policy from the national level to the European Union. In 2013, Croatia became the 28th member. Besides these major events, the European Union was built on a complex maze of treaties and agreements, steadily widening and deepening the economic integration between its members.

Ever since its initial foundation, the European Union has also been accompanied by controversy. Clear examples of disagreement are various cases of failed expansions. For instance, the UK's membership was vetoed by France in 1961; Spain's application was rejected by the European Council in 1962; Norway's citizens voted against joining the union in 1967 and 1992. Yet, until recently, the union has always grown in size and scope. In 2016, for the first time, a member state - the UK - voted to leave the union. Anti-European Union sentiment 
has also been on the rise in other countries. What is driving this growing dissatisfaction with European integration?

\subsection{Discontent with the European Union: a theory-Based View}

Let us use a stylized version of our model to answer this question. There are two types of countries, $W$ and $E$. Half of the workers live in $W$ countries and the other half in $E$ countries. Industries are characterized by a specialization parameter $\delta_{i}$ such that productivity in industry $i$ is $\pi_{n}^{i}=1-\delta_{i}$ in $W$ countries and $\pi_{n}^{i}=1+\delta_{i}$ in $E$ countries. The specialization parameter $\delta_{i}$ is independent of $i$ and uniformly distributed on $[-1,1]$, so $\int_{i_{1}}^{i_{2}} \pi_{n}^{i} d i=1$ and $\int_{i_{1}}^{i_{2}} \ln \pi_{n}^{i} d i=\ln 2-1$ for any interval $\left[i_{1}, i_{2}\right] \subseteq[0,1]$ and any country $n$.

Assume that, within each country, workers are uniformly distributed across industries: $L_{n}^{i}=L_{n}$ for all $i \in[0,1]$. The set of industries in country $n$ whose workers oppose the union is $\left\{i \in[0,1]: \Delta W_{n}^{i}(t, \mathcal{U})<0\right\}$. We define $\Omega_{n}$ as the measure or size of this set, which equals the share of country $n$ 's workers who oppose the union.

Our specification of factor endowments implies that, for all countries and union types, the average income in union industries equals the average income in global industries. Thus, the share of domestic income of workers in global industries is not affected by the depth and breadth of the union. The latter creates redistribution across union industries only.

Consider first a union of depth $t$ which contains only countries of type $W$. Then, all residents of the union support it: $\Omega_{n}=0$. The reason is that $G_{n}^{\text {Intra }}(t, \mathcal{U})>0$ and $G_{n}^{\text {Inter }}(t, \mathcal{U})=0$. Moreover, everyone supports the union more strongly the deeper it is $\left(\partial \Delta W_{n}^{i} / \partial t>0\right)$. Thus, everyone's preferred union is the deepest one, with $t=1-\tau$. One can think of this as the situation of the European Union early on, when countries were more similar in factor endowments and most of the gains from trade were of the intra-industry type.

Consider instead an enlarged union whose residents are evenly split between countries of type $W$ and countries of type $E$. Now both $G_{n}^{\text {Intra }}(t, \mathcal{U})>0$ and $G_{n}^{\text {Inter }}(t, \mathcal{U})>0$, so the union provides more gains to the representative worker than before. But these gains are not equally shared. In $W$ countries, for instance, union industries with $\delta_{i}<0$ run trade surpluses and have greater gains from union membership than the representative worker, while union industries with $\delta_{i}>0$ run trade deficits and have smaller gains from trade than the representative worker. All workers in global and local industries support the union, and the question is how many workers in local industries do the same.

Workers in an industry $i \in(\tau, \tau+t)$ in a $W$ country face an income loss from integration 
whenever $\delta_{i}>0$, and they oppose the union if:

$$
\ln \left(1-\delta_{i}\right)<\frac{t}{\sigma-1}\left[\ln \frac{L_{n}}{L_{U}}-(1-\ln 2) \sigma\right]
$$

It follows that the share of country $n$ 's residents opposing the union is:

$$
\Omega_{n}=\frac{t}{2}\left[\left(\frac{2}{e}\right)^{\sigma} \frac{L_{n}}{L_{U}}\right]^{\frac{t}{\sigma-1}}
$$

such that

$$
\frac{\partial \Omega_{n}}{\partial t}>0 \Leftrightarrow t<\bar{t}_{n} \equiv \frac{\sigma-1}{\sigma(1-\ln 2)+\ln \left(L_{U} / L_{n}\right)} .
$$

Essentially, the set of losers contains all workers in comparative-disadvantage industries that suffer an income loss that exceeds a threshold. This threshold reflects the gains for the representative worker from the reduction in the cost of living that results from union membership. This reduction, and therefore the threshold, is larger the smaller is the country.

With a union of dissimilar countries, the effect of union depth is nonlinear. The set of affected industries grows linearly, and these are the industries with losers. However, among affected industries, fewer are net losers as union depth increases. In this example, these two effects combine in a non-monotonic way. Initially, as the union becomes deeper the first effect dominates and opposition to the union grows. However, provided that

$$
\sigma[\tau+(1-\tau) \ln 2]+\ln \frac{L_{n}}{L_{U}}<1
$$

opposition to the union peaks at a union depth $\bar{t}_{n}<1-\tau$ and then declines as depth increases further.

The intuition provided by this example is that a union becomes unstable and fragile when its member countries have sufficiently different patterns of comparative advantage, and thus sufficiently large imbalances in intra-union trade. While such a union creates greater efficiency gains than a union among homogeneous countries, those gains accrue to consumers and to winners in each country's export industries. Instead, losers emerge whose welfare is reduced by the union. A marginal reduction in union depth is likely to be one strategy to reduce their number. However, another and more efficient strategy may be a "big push" towards much closer integration. As Equation (43) highlights, this second possibility exists when a fully integrated common market is valuable enough, i.e., when gains from intra-industry trade are high ( $\sigma$ is low) and trade without union policies is limited ( $\tau$ is low). 
Both Equation (43) and Equation (41) show that opposition to a heterogeneous union is greater in larger member countries. The reason, intuitively, is that residents of larger economies stand to gain less as consumers from the common union market. Therefore, they are more sensitive to the losses they may suffer as producers in import-competing industries. Finally, note that Equation (41) measures the share of industries in country $n$ that oppose the union. We have assumed for ease of exposition that workers are uniformly distributed across industries, but it is straightforward to relax this assumption. Then, popular opposition to the union will be greater in countries with a larger share of the workforce in low-productivity, comparative-disadvantage sectors. These two forces-lower consumer gains in larger economies, and more numerous losers in countries with greater employment in import-competing industries - are the two predictions that we examine next.

Before doing this, it is worth also noting that ultimately the union becomes unpopular because countries are not implementing redistributive policies that ensure an equal or fair sharing of the gains from union membership. With such policies in place, union membership would be universally supported.

\subsection{Discontent with the European Union: the data}

The Eurobarometer, a series of public opinion surveys conducted regularly on behalf of the European Commission, contains data that can be used to study how attitudes towards the European Union vary across countries and have evolved over time. These surveys address a variety of issues relating to the European Union and have been conducted both in EU countries and in prospective member states. In this section, we focus on one question: "In general, does the EU conjure up for you a very positive, fairly positive, neutral, fairly negative or very negative image?" Compared to the data used to draw Figure 1, on the perceived economic benefits from the European Union, answers to this question are available for all 28 current European Union countries, but only for the more recent period from 2000 to 2018. For both questions, the share of respondents with a positive view exhibits slightly less variation, while the margin between negative and undecided answers appears to move more. This is already evident from Figure 1. For this reason, and to be closer to the goal of studying euroskepticism, we choose as our main variable of interest the share of respondents with a "fairly negative or very negative image" of the European Union. ${ }^{10}$

\footnotetext{
${ }^{10}$ Yet, there is a strong negative correlation between the share of respondents with negative and positive views (-0.83) and both questions yield the same qualitative patterns.
} 


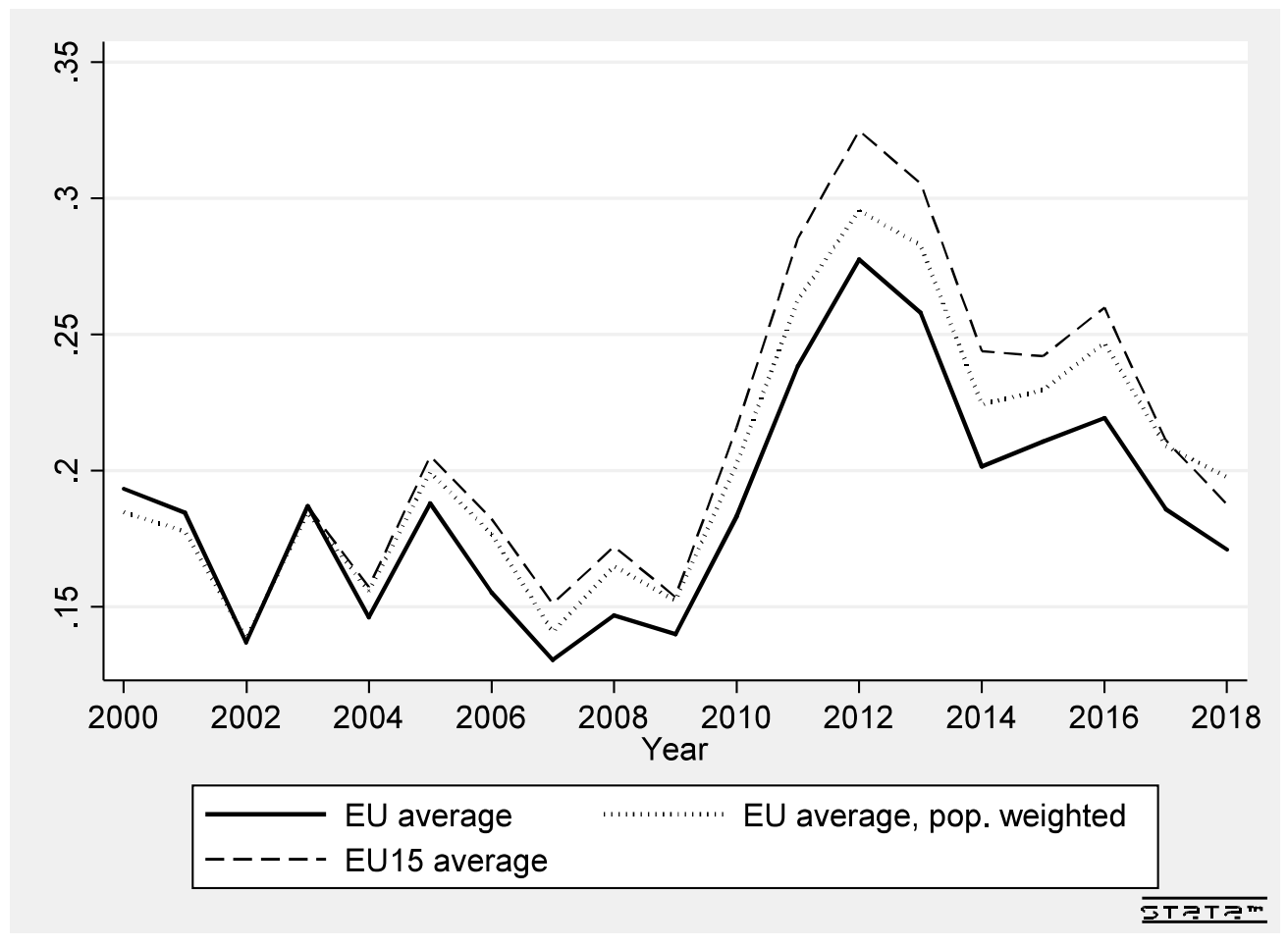

Figure 2: Negative image of the EU, averages. Source: Eurobarometer.

Figure 2 plots the evolution over time of this measure of discontent. The solid line corresponds to the European Union simple average, the dashed line is the simple average for the sample of 15 member countries in 2000, and the dotted line is the European Union average weighted by population. A number of facts stands out. First, the figure shows a growing dissatisfaction that started around 2007 and continued until 2012. Clearly, one culprit is the eurozone debt crisis. However, the deterioration of the image of the European Union seems to predate the crisis. Second, the dashed line (EU 15 average) is above the solid line (EU average), implying that new members tend to have a more positive view of the European Union. Moreover the difference seems to have grown, at least until 2016. This means that dissatisfaction has grown especially in countries that were part of the European Union before the accession of new members and suggests that "enlargement fatigue" may have played a role. Third, the dotted line (population weighted average) is closer to the dashed line (EU 15 average), confirming that new members tend to be smaller in size. Finally, all lines display strong co-movements, suggesting that some of the driving forces may be common to many countries.

As a next step, we do a simple variance decomposition exercise. We ask what fraction of the variance in attitudes towards the European Union is accounted for by time-specific com- 


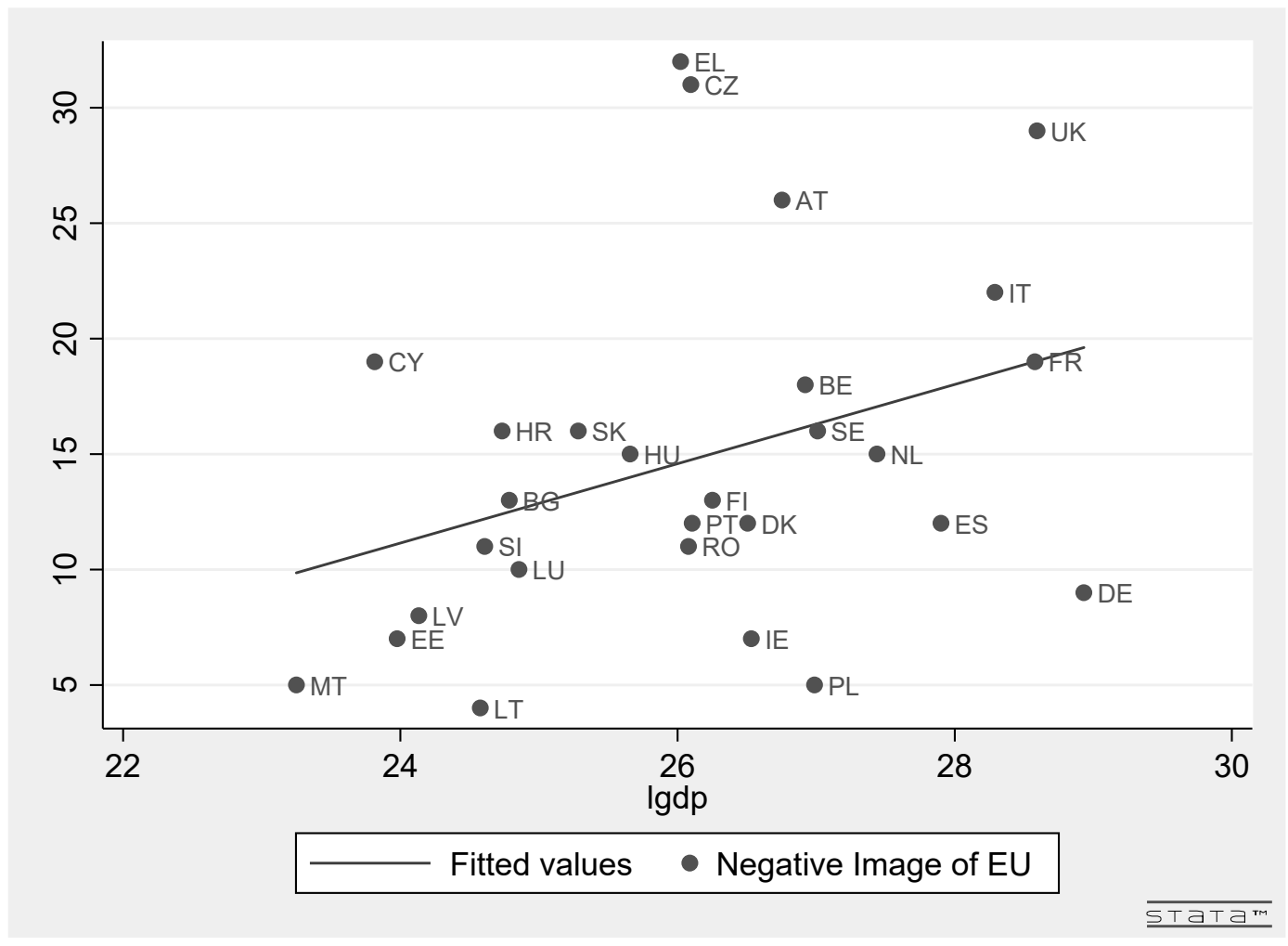

Figure 3: Negative image of the EU by economic size. Data for 2017. Source: Eurobarometer and Eurostat.

mon factors and country-specific factors. We do this by comparing the $R$-squared obtained by regressing the share of respondents with a negative image of the European Union on year and country fixed effects. This exercise shows that the largest source of variation is cross sectional: country fixed effects alone explain $49 \%$ of the data, while year dummies accounts for $17 \%$. We now discuss the main factors that, according to our model, may explain the observed time and cross-sectional variation.

Starting from the latter, our model suggests that an important determinant of preferences for the union is economic size: larger and richer countries benefit relatively less from adopting union policies. To have a first sense of whether this prediction is consistent with the data, Figure 3 shows a scatter plot of respondents with a negative image of the European Union (vertical axis) against the logarithm of aggregate GDP (horizontal axis) in 2017. ${ }^{11}$ The picture shows a clear positive association between size and a negative image of the European Union, highlighted in the graph by the linear regression line. The figure is also useful to

\footnotetext{
${ }^{11}$ We use nominal GDP to focus on economic size net of price effects. However, results are qualitatively similar when using real GDP.
} 
visualize the cross-sectional variation in the data. It is immediate to see that countries differ substantially in their attitude towards the union. The most pro-Europe members states (less than $10 \%$ of respondents with a negative view) include small countries such as Malta, Lithuania and Ireland, but also Germany, despite its size. Countries with a strong antiEurope attitude (more than $20 \%$ of respondents with a negative view) include several large economies, such as the UK and Italy, but also Greece.

Regarding the time variation, our theory suggests that European Union enlargement may be an important factor. While a bigger union is better at promoting trade, it may lead to more disagreement if new members make the union more diverse. This is indeed what happened. As figure 4 shows, enlargements have made the European Union more heterogeneous in economic terms. The figure shows the average aggregate GDP of union members relative to the average GDP of the six founding members. The figure confirms that, almost invariably, each enlargement included countries with an economic size on average smaller than the initial members. Moreover, the sharpest drop in average country size happens after the 2004 enlargement. The European Union has also become more diverse in terms of factor endowments: since 2004, new member states were not just smaller, but also on average poorer and with lower levels of education.

Our theory then suggests that enlargement fatigue could be driven, at least in part, by a dissatisfaction of the larger economies with the extent of economic integration with much smaller and poorer economies. Increased trade with countries with different factor endowments may have had redistributive effects that heightened disagreement over the union within countries. This argument is consistent with the simple observations that the UK has always been one of the largest economies in the European Union and that UK workers employed in sectors more exposed to import competition from Eastern Europe voted predominantly to leave the union. Besides the enlargement, our theory also suggests that the attitude towards the European Union may also be affected by any other changes that make workers in a country more exposed to import competition from the union.

\subsection{Size, import Competition and attitudes towards the European Union}

We now study the relationship between economic size, import competition and discontent towards the European Union more systematically. To this end, we have collected a number of additional variables sourced from Eurostat. To measure aggregate economic size, we consider separately the logarithm of population and of GDP per capita. Breaking down the two components of size is useful as they exhibit significantly different variation over time 
Union average GDP relative to EEC 6

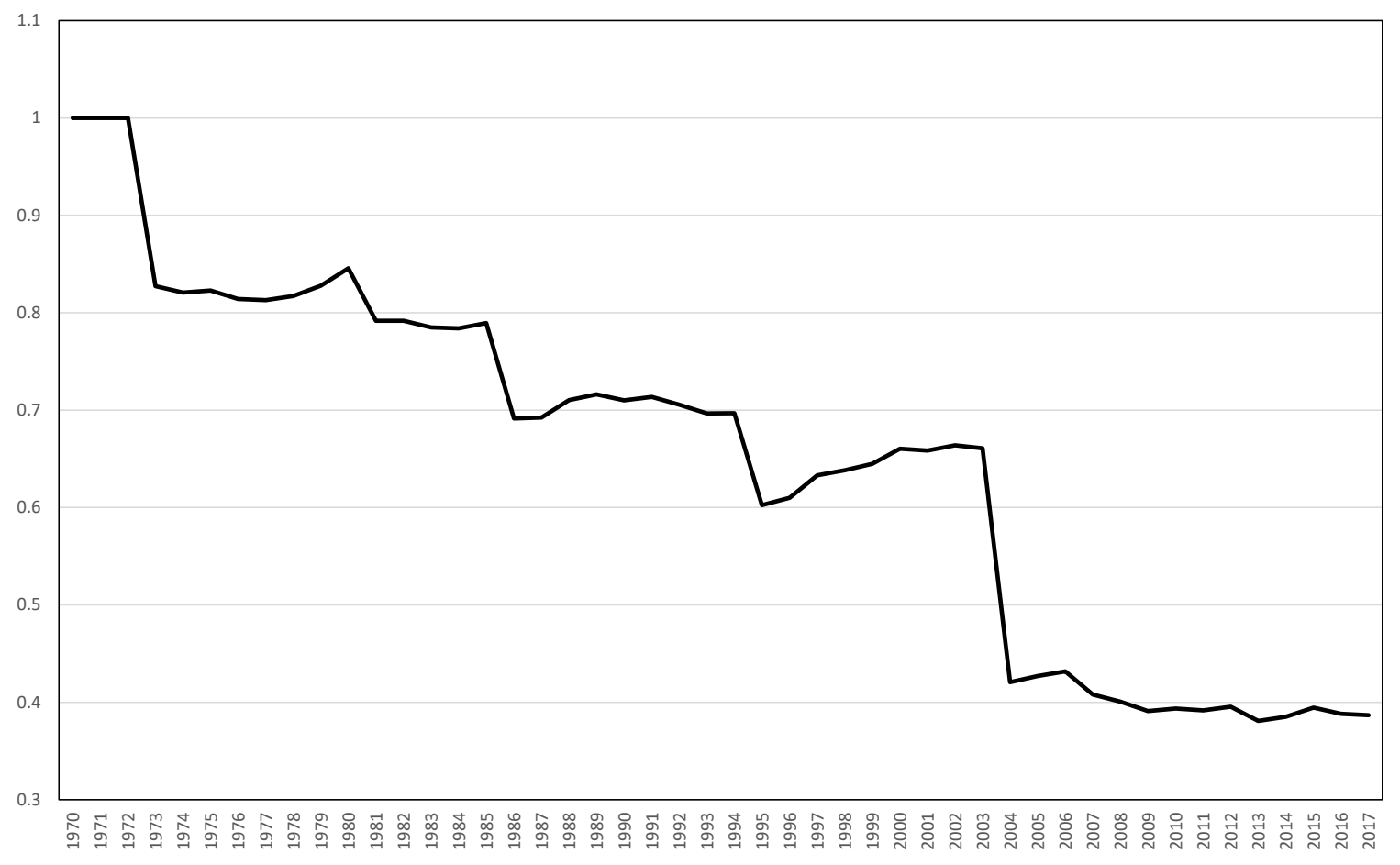

Figure 4: Average aggregate GDP of EU member states relative to the six founding countries. Source: Eurostat.

and across countries.

Next, we are interested in measuring workers' exposure to import competition from other European Union members. Our model suggests that workers employed in sectors with a comparative disadvantage relative to other countries in the European Union should have a more negative view of the union. To test this prediction, we have collected data on employment and the value of production at a detailed sectoral level (NACE classification, level 2) from the Structural Business Statistics (SBS) database, describing the structure and performance of businesses across the European Union. Then, for each country-year, we computed the fraction of employment in industries with a share of domestic production lower than the income share of the country in the European Union. ${ }^{12}$ According to our model, this variable captures the share of workers in industries with a comparative disadvantage who might lose income due to import competition from the European Union. ${ }^{13}$ It measures

\footnotetext{
${ }^{12}$ We compute this measure for industry only and disregard construction, distributive trades and services mostly because of the high number of missing values in the latter sectors. Moreover, traded goods are heavily concentrated in industry.

${ }^{13}$ The model implies that a country is keener on union membership if it has more workers in union industries with net exports to the union. Given that in reality we cannot distinguish between union and
} 


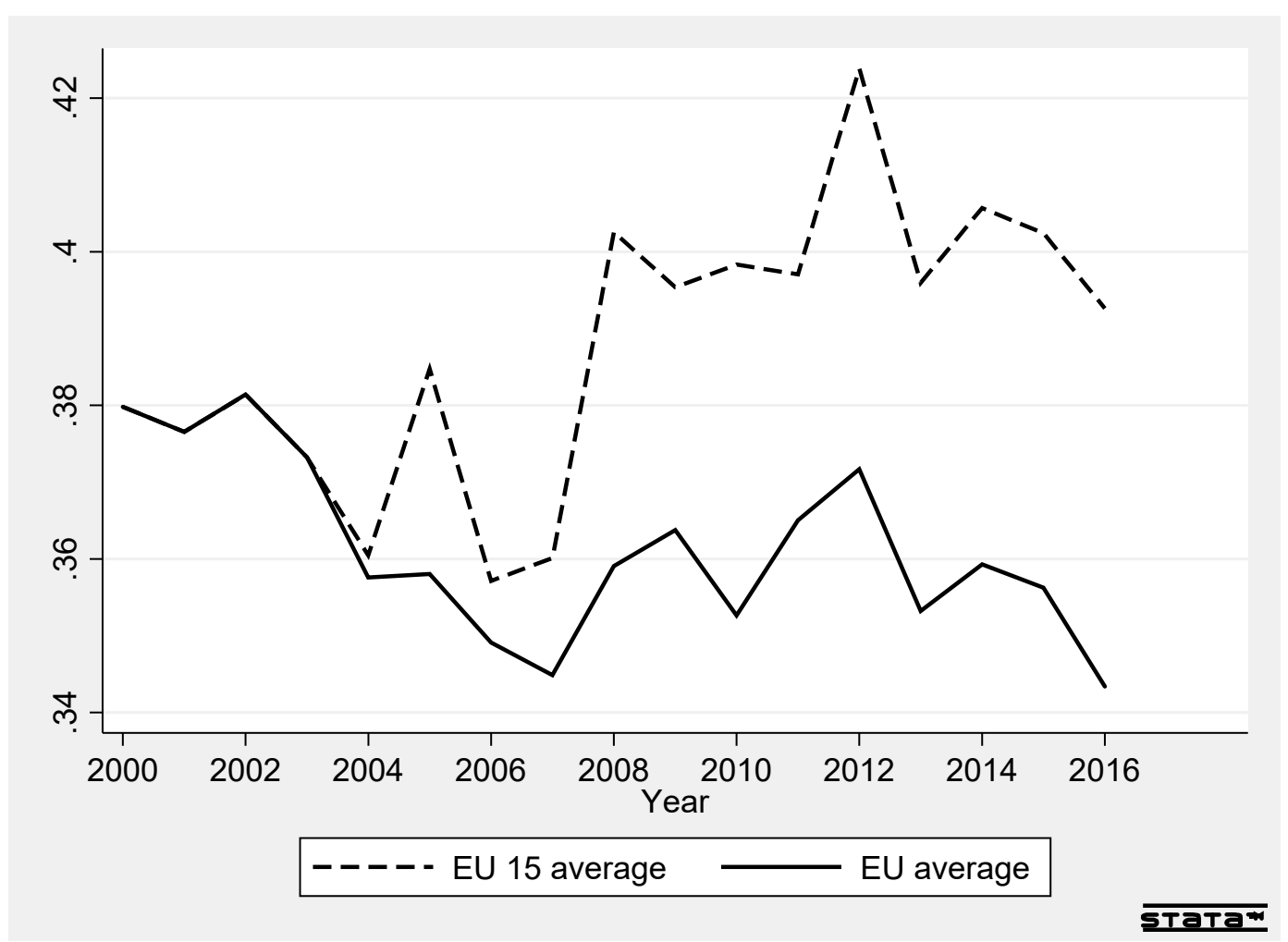

Figure 5: Employment share exposed to import competition from the EU. Source: Eurostat SBS.

aversion to the union net of size effects, which are instead captured separately by GDP, and other price effects.

Exposure to import competition, which is available from 2000 to 2016, varies both because the structure of employment and production varies in all countries, but also because the composition of the European Union changes over time. For this variable, Figure 5 plots the evolution of the European Union simple average (solid line) and the simple average for the sample of 15 member countries in 2000 (dashed line). The rise in the dashed line and its divergence from the solid line after 2004 indicate that the enlargement has made workers in the initial EU 15 countries more exposed to import competition from new members, whose workforce is more concentrated in sectors with net exports. Interestingly, the fact that the dashed line (EU 15 average) keeps rising suggests that import competition from new member states has grown even after the accession. Moreover, comparing Figure 5 to Figure 2 it is easy to see that exposure to import competition in the EU 15 countries and a negative attitude

global industries, and that EU countries trade predominantly with each other, we compute exposure to EU import competition across all industries. 


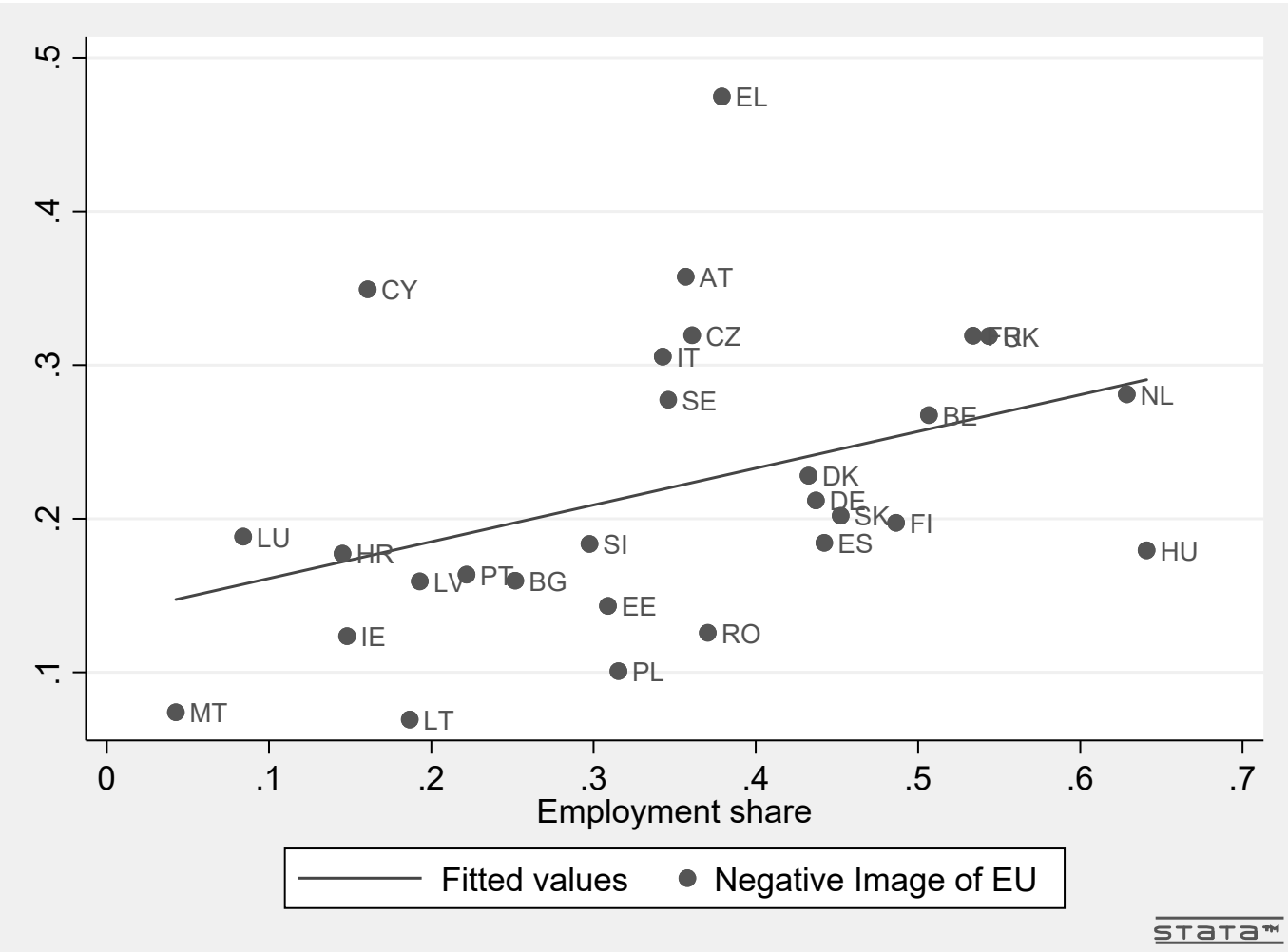

Figure 6: Negative image of the EU and employment share exposed to import competition in 2016. Source: Eurostat (SBS) and Eurobarometer.

towards the European Union display a similar evolution, both peaking in 2012.

Figure 6 shows instead a scatter plot of respondents with a negative image of the European Union (vertical axis) against the share of workers exposed to import competition from the European Union (horizontal axis) in 2016. The picture shows a clear positive association between the fraction of workers in comparative disadvantage industries and a negative image of the European Union, highlighted by the linear regression line.

Besides these variables, which have clear counterparts in our model, we also consider a number of additional controls. Since our theory suggests that exporters are keener on economic integration than importers, we also consider net exports to the European Union, normalized by the volume of trade with the European Union. The existing literature suggests that negative attitudes towards the European Union are typically associated with economic hardship, low levels of education and inequality. There is also a popular view that immigration may have triggered an anti-Europe sentiment. Hence, to account for these complementary explanations, we control for the unemployment rate of the active population (in percentage points), as a measure of economic crises; for the share of working-age population 
Table 1: Negative image of the EU: Country fixed effects

\begin{tabular}{|c|c|c|c|c|c|c|}
\hline \multicolumn{7}{|c|}{ Dependent variable: Negative Image of EU } \\
\hline & (1) & $(2)$ & (3) & (4) & $(5)$ & $(6)$ \\
\hline \multirow[t]{2}{*}{ Log population } & $0.370^{* *}$ & & $0.559 * * *$ & $0.301 * *$ & $0.376^{*}$ & 0.237 \\
\hline & $(0.136)$ & & $(0.127)$ & $(0.121)$ & $(0.200)$ & $(0.199)$ \\
\hline \multirow[t]{2}{*}{ Log GDP pc } & 0.018 & & 0.035 & -0.034 & 0.012 & $-0.164 * *$ \\
\hline & $(0.020)$ & & $(0.027)$ & $(0.028)$ & $(0.043)$ & $(0.065)$ \\
\hline \multirow[t]{2}{*}{ EU imp. comp. (\% of emp.) } & & $0.163^{* * *}$ & $0.160^{* * *}$ & $0.087 * * *$ & $0.164 * * *$ & $0.118^{* *}$ \\
\hline & & $(0.041)$ & $(0.041)$ & $(0.027)$ & $(0.051)$ & $(0.053)$ \\
\hline \multirow[t]{2}{*}{ EU net exports } & & & & $0.331 * * *$ & 0.093 & 0.123 \\
\hline & & & & $(0.087)$ & $(0.144)$ & $(0.102)$ \\
\hline \multirow[t]{2}{*}{ Unemployment \% } & & & & $0.008^{* *}$ & $0.010^{* *}$ & $0.005^{* *}$ \\
\hline & & & & $(0.003)$ & $(0.004)$ & $(0.002)$ \\
\hline \multirow[t]{2}{*}{ Tertiary education } & & & & $0.402^{* * *}$ & 0.335 & -0.144 \\
\hline & & & & $(0.131)$ & $(0.326)$ & $(0.255)$ \\
\hline \multirow[t]{2}{*}{ Gini } & & & & -0.198 & 0.350 & $0.686^{* *}$ \\
\hline & & & & $(0.170)$ & $(0.300)$ & $(0.305)$ \\
\hline \multirow{2}{*}{ Immigrants $(\%)$} & & & & & -0.538 & -0.283 \\
\hline & & & & & $(0.367)$ & $(0.330)$ \\
\hline Country Fixed Effects & Yes & Yes & Yes & Yes & Yes & Yes \\
\hline Year Fixed Effects & No & $\mathrm{No}$ & $\mathrm{No}$ & $\mathrm{No}$ & $\mathrm{No}$ & Yes \\
\hline Clusters & Year & Year & Year & Year & Year & No \\
\hline Observations & 479 & 414 & 414 & 374 & 231 & 227 \\
\hline R-squared & 0.517 & 0.523 & 0.572 & 0.739 & 0.779 & 0.887 \\
\hline
\end{tabular}

(25-64) with tertiary education; for the Gini coefficient of the net income distribution, as a measure of inequality; and for the stock of immigrants as a share of population. Most of these variables are available for all 28 countries over the period 2000-2018. ${ }^{14}$

We start by studying correlates of changes in the negative attitude towards the European Union, with the caveat that, for some variables of interest, the most meaningful variation is cross sectional. Table 1 reports panel regressions with country fixed effects and standard errors clustered at the year level. Column (1) shows that the coefficients for both components of economic size are positive, but only population is statistically significant (at the $5 \%$ level).

\footnotetext{
${ }^{14}$ However, exposure to import competition is available until 2016 only. The stock of immigrants has several missing observations, especially in the first years of the sample. For this reason, we do not include it in our main specifications.
} 
This is not too surprising, given that changes in GDP per capita over time are likely to capture cyclical factors such as the severity of the crisis, which may in turn prompt more negative views. Column (2) shows, as expected, that changes in import competition from the European Union are strongly correlated with a negative image of the union. The coefficient is significant the $1 \%$ level. Column (3) confirms the previous findings when all these variables are included simultaneously.

In column (4) we include all the other control variables, except immigration, which has several missing values. The coefficients for population and import competition remain highly significant. Regarding the new controls, perhaps surprisingly, the coefficient for net exports to the European Union and tertiary education turn out to be positive and significant. However, as we shall see, these findings are not robust, which may reflect the fact that changes in these variables over time are hard to interpret. ${ }^{15}$ An increase in the unemployment rate is associated with a more negative view of the European Union, consistent with the view that the crisis has fueled anti-Europe sentiments. Changes in the Gini coefficient have instead no statistically significant correlation. In column (5) we also include the share of immigrants. Despite the loss of observations, the coefficients for population and import competition remain significant.

Finally, in column (6) we include year fixed effects, thereby removing any common factor. Despite the demanding specification, the positive coefficient for exposure to import competition remains highly significant. Interestingly, we now find that differential increases in inequality, as captured by the Gini coefficient, are associated with a more negative attitude towards the European Union. The same applies to the variables capturing macroeconomic performance: a fall in GDP per capita or an increase in the unemployment rate relative to other countries is correlated with a lower support for the union.

Next, we focus on the cross sectional variation in the data. Table 2 replicates columns (1)-(5), but with year fixed effects instead of country dummies, and clustering standard errors at the country level. The coefficients for both components of economic size are still positive, but now only GDP per capita is statistically significant (at least at the $5 \%$ level). Hence, rich countries tend to have a more negative view of the European Union. The coefficient for import competition is also positive and significant (except in one case). Interestingly, in the cross section, net exports to the European Union are strongly correlated with a less negative image of the union. These results confirm that countries with higher employment in

\footnotetext{
${ }^{15}$ For instance, changes in net exports to the EU are likley to capture cyclical movements in the current account balance rather than structural trade patterns.
} 
Table 2: Negative image of the EU: Year fixed effects

\begin{tabular}{|c|c|c|c|c|c|}
\hline \multicolumn{6}{|c|}{ 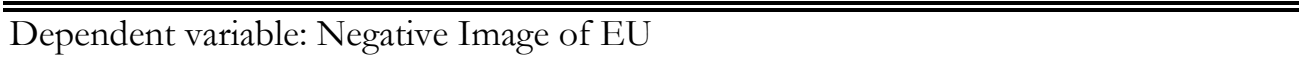 } \\
\hline & (1) & (2) & (3) & (4) & (5) \\
\hline \multirow[t]{2}{*}{ Log population } & 0.011 & & 0.004 & 0.008 & -0.001 \\
\hline & $(0.009)$ & & $(0.009)$ & $(0.009)$ & $(0.011)$ \\
\hline \multirow[t]{2}{*}{ Log GDP pc } & $0.042 * *$ & & $0.046^{* * *}$ & $0.060 * * *$ & $0.071 * *$ \\
\hline & $(0.016)$ & & $(0.015)$ & $(0.019)$ & $(0.028)$ \\
\hline \multirow[t]{2}{*}{ EU imp. comp. (\% of emp.) } & & $0.129 *$ & 0.094 & $0.164^{* *}$ & $0.340^{* * *}$ \\
\hline & & $(0.070)$ & $(0.067)$ & $(0.074)$ & $(0.089)$ \\
\hline \multirow[t]{2}{*}{ EU net exports } & & & & $-0.176^{* * *}$ & $-0.239 * * *$ \\
\hline & & & & $(0.046)$ & $(0.052)$ \\
\hline \multirow[t]{2}{*}{ Unemployment \% } & & & & 0.005 & $0.006^{* *}$ \\
\hline & & & & $(0.003)$ & $(0.003)$ \\
\hline \multirow[t]{2}{*}{ Tertiary education } & & & & -0.108 & $-0.345^{* *}$ \\
\hline & & & & $(0.139)$ & $(0.157)$ \\
\hline \multirow[t]{2}{*}{ Gini } & & & & $-0.528^{*}$ & -0.219 \\
\hline & & & & $(0.309)$ & $(0.336)$ \\
\hline \multirow[t]{2}{*}{ Immigrants (\%) } & & & & & 0.139 \\
\hline & & & & & $(0.172)$ \\
\hline Country Fixed Effects & No & No & No & No & No \\
\hline Year Fixed Effects & Yes & Yes & Yes & Yes & Yes \\
\hline Clusters & Country & Country & Country & Country & Country \\
\hline Observations & 479 & 414 & 414 & 374 & 227 \\
\hline R-squared & 0.274 & 0.229 & 0.316 & 0.468 & 0.585 \\
\hline
\end{tabular}

import-competing sectors and higher imports relative to exports to the European Union tend to dislike the union more. There is also some evidence that tertiary education is correlated with a more favorable view of the European Union.

The relatively weak correlation between education and preferences for the European Union seems in contrast with existing evidence within countries. For instance, for the UK, Becker, Fetzer and Novy (2017), Pastor and Veronesi (2019) and others find that voting for Brexit is associated with low educational attainment. A special survey by the European Commission (2016) also shows that education markedly affected the attitude of Europeans towards European Union enlargement: $51 \%$ of those who left full-time education at the age of 20 or later favored European Union enlargement, compared to $35 \%$ of those who left at age 15 . 
Yet, a discrepancy between results within and across countries is consistent with our model, which highlights different sources of disagreement over union policies across and within countries. From this perspective, it is useful to look at how attitudes towards the European Union vary with the level of education by country. Data from the Eurobarometer stratified by education groups confirms that the share of respondents with a "very positive or fairly positive" image of the European Union in 2017 is on average much higher (48\%) among individuals who left education at the age of 20 or later than among those who left at age 16-19 (36\%) or below (29\%). But do these differences between more and less educated people vary systematically with a country's income level? In other words, are highly educated workers more pro-Europe in richer countries? The answer to this question is provided by Figure 7, which shows the share of positive views among respondents who left education at age 20+ relative to those who left school at age 16-19, against the log of GDP per capita in 2017. This scatter plot confirms that in all countries but Hungary positive views are more frequent among better educated people. Strikingly, however, this difference increases with income. In particular, the coefficient of a linear regression is 0.13 , with a standard error of $0.05 .^{16}$

What can we learn from these results? The evidence suggests that attitudes towards the European Union mirror the distribution of the gains from intra-EU trade. It broadly supports the predictions of our theory. Smaller and poorer countries, with a larger share of employment in export-oriented sectors, reap greater benefits from accessing the larger union market. Within countries, educated workers are more likely to benefit from trade because they tend to be specialized in industries where products are more differentiated and gains from variety higher (e.g., Epifani and Gancia 2008). At the same time, as in models of interindustry trade, gains are larger for workers in export industries, such as the high-skilled in rich countries, then for those in import-competing industries. ${ }^{17}$

In line with this view, there is a growing empirical literature suggesting that exposure to import competition has increased the support for parties and politicians with protectionist, populist, and nationalist agendas (Colantone and Stanig 2018a, b). While import competition is often perceived as a major threat of globalization, export opportunities can instead help explain the support for international unions. The German case is of particular inter-

\footnotetext{
${ }^{16}$ A similar scatterplot using data on respondents with a negative view of the EU yields very similar results: respondents with lower education are more anti-EU in richer countries.

${ }^{17} \mathrm{~A}$ recent literature uses structural models to quantify the economic gains from the EU. The results are consistent with our view. For instance, Caliendo et al. (2017) and Mayer, Vicard and Zignago (2019) find that new member states were the largest winners from EU enlargement.
} 


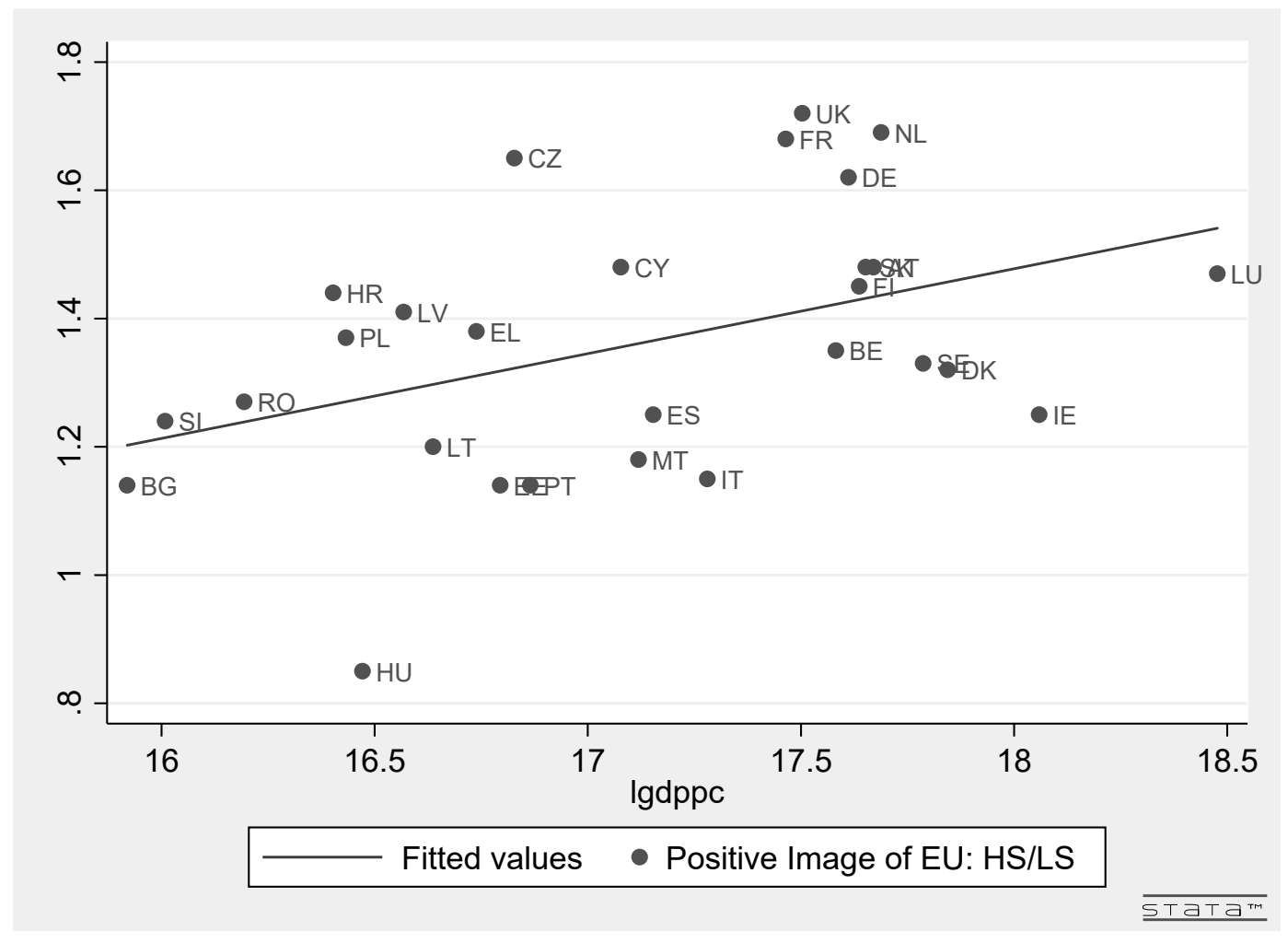

Figure 7: Economic size and support for the EU by education. Positive image of the EU in 2017 among high-skill respondents (who left education at age 20+) relative to low-skill respondents (who left education at age 16-19). Source: Eurobarometer and Eurostat.

est here. Dauth, Findeisen and Suedekum (2014) find that the rise in trade with Eastern Europe caused job losses in German regions specialized in import-competing industries, but that these losses were more than compensated by employment gains in export-oriented industries. Dippel, Gold and Heblich (2015) also find that German regions that gained better export opportunities reduced their vote share for extreme right-wing parties, at the same time as it increased in regions that faced sharper import competition.

These results then offer some insight on the persistent support for European integration in Germany. While Germany is the largest economy in Europe, it is also an export powerhouse, with a trade surplus in a majority of industries. Our framework then suggests that German workers are uncommonly keen on the Single Market because they are more likely to be employed in sectors with positive net exports to the European Union. 


\section{Concluding Remarks}

We have shown how the support for international unions can become weaker as member countries become more dissimilar in economic size and factor endowments. The expansion of the WTO, from 23 to 164 countries, the enlargement of the European Union, especially after 2004, the rise of China and the emergence of global supply chains have all fostered trade between an increasingly diverse set of countries. While all these phenomena raise the potential gains from trade, our model shows that they may also undermine the political support for the process of economic integration.

If an international union comprises countries that are sufficiently similar, it can grow without facing any opposition. An intra-union pattern of comparative advantage due to differences in endowments, instead, increases the value of the union but also creates winners and losers. This redistribution may undermine the support for the union even when the country as a whole would benefit from union membership. Moreover, differences in economic size implies that, in the presence of any cost of integration, larger economies would prefer a shallow union, while smaller ones prefer deeper integration.

What policies could then be adopted to restore the support for more economic integration, and hence to reap additional gains from trade? If disagreement over the value of the union is between winners and losers within countries, domestic redistribution may suffice to solve it. This was clear in the theory developed here. A further complication can arise once we relax some of the assumptions of the theory and it becomes possible that some countries lose as a whole from further integration (relaxing the unit elasticity assumption across industries would do this). If then the disagreement is between countries that differ in size and income, solving it requires some form of international redistribution. This may be more difficult to achieve, given that such policies tend to be politically costly and hard to implement.

Alternatively, support for the union may be restored by making the union more attractive, for instance by deepening integration in areas that are less contentious. In this paper, we have taken the size and scope of the union as given. However, our model shows how changes on one margin affect preferences for the other. For instance, as we have already argued, the accession of smaller and poorer countries, which want deeper integration, may trigger a deepening of the union which may go against the desire of larger and richer countries. Studying more formally the interaction between the size and scope of economic unions may help shed new light on recent phenomena and seems a fruitful avenue for future research.

Finally, we cannot fail to notice that much of the political debate about European integra- 
tion, and especially about Brexit, has focused on migration. Migration features prominently on the front pages of newspapers, in the narratives of politicians, and so on. At the same time, we cannot fail to notice either that migration flows within Europe are small relative to trade flows. According to Eurostat demography figures, out of 512 millions residents of the European Union in 2017, only 22 million (4.3\%) were non-EU citizens and only 17 million (3.3\%) were EU citizens living in a country other than their country of citizenship. These are very small numbers. ${ }^{18}$ Instead, intra-EU trade in goods (19.6\%) and services (7.4\%) add up to $27 \%$ of the total GDP of the European Union. These are not small numbers. Clearly we still live in a world in which trade in goods and services is quantitatively more important than migration.

These two observations jointly create a puzzle. Why does migration attract so much attention in the political debate and in the media, despite being such a small phenomenon in the European Union? Perhaps politicians and journalists simply blow up the issue of migration out of proportion to its true welfare impact. Supporting this view, in our regressions we do not find that migration flows predict support for the European Union across countries. However, this negative result might just reflect a limitation of our empirical specifications. Therefore, we cannot totally discard the alternative that small migration flows may have large welfare effects. One possibility is that these large welfare effects are of a non-economic nature. Assessing this hypothesis would require a very different modeling framework than the one we offered here.

Another possibility, closer to our analysis, is that migration flows have more controversial economic consequences than trade flows of a similar magnitude. Although we have written a classic model of international trade without factor mobility, our setup suggests one reason why this could be the case. Trade in factors is as effective as trade in goods at reaping the gains from inter-industry trade. But those are precisely the gains that we have shown to be associated with acute distributive tensions. Trade in goods also delivers gains from intraindustry trade that are universally shared. Trade in factors cannot do that. When workers move from one country to another, they can reduce the differences in factor endowments between the two countries. However, the varieties these workers produce cannot be consumed by both countries simultaneously.

\footnotetext{
${ }^{18}$ In comparison, $14.4 \%$ of the US population is foreign-born, and as many as $41.5 \%$ of Americans live outside their state of birth.
} 


\section{REFERENCES}

[1] Alesina, Alberto, Ignazio Angeloni, and Federico Etro. 2005. International Unions. American Economic Review 95(3): 602-615.

[2] Alesina, Alberto, Enrico Spolaore, and Romain Wacziarg. 2000. Economic Integration and Political Disintegration. American Economic Review 90(5): 1276-1296.

[3] Alesina, Alberto, and Romain Wacziarg. 1999. Is Europe Going Too Far? CarnegieRochester Conference Series on Public Policy 51(1): 1-42.

[4] Autor, David, David Dorn, Gordon H. Hanson, and Kaveh Majlesi. 2017. Importing Political Polarization? The Electoral Consequences of Rising Trade Exposure. NBER Working Paper No. 22637.

[5] Bagwell, Kyle, Robert W. Staiger. 2016. The Design of Trade Agreements. In Handbook of Commercial Policy, Vol. 1A, edited by Kyle Bagwell and Robert W. Staiger, 435-529. Amsterdam: Elsevier.

[6] Becker, Sascha O., Thiemo Fetzer, and Dennis Novy. 2017. Who Voted for Brexit? A Comprehensive District-Level Analysis. Economic Policy 32(92): 601-650.

[7] Berglof, Erik, Mike Burkart, Guido Friebel and Elena Paltseva. 2008. Widening and Deepening: Reforming the European Union. American Economic Review, Papers and Proceedings 98(2): 133-137.

[8] Berglof, Erik, Mike Burkart, Guido Friebel, and Elena Paltseva. 2012. Club-in-the-Club: Reform under Unanimity. Journal of Comparative Economics 40(3): 492-507.

[9] Bolton, Patrick, and Gerard Roland. 1996. Distributional Conflicts, Factor Mobility and Political Integration. American Economic Review 86(2): 99-104.

[10] — 1997. The Breakup of Nations: A Political Economy Analysis. Quarterly Journal of Economics 112(4): 1057-1090.

[11] Buera, Francisco J., Alexander Monge-Naranjo, and Giorgio E. Primiceri. 2011. Learning the Wealth of Nations. Econometrica 79(1): 1-45.

[12] Caliendo, Lorenzo, Luca D. Opromolla, Fernando Parro, and Alessandro Sforza. 2017. Goods and Factor Market Integration: A Quantitative Assessment of the European Union Enlargement. NBER Working Paper No. 23695. 
[13] Casella, Alessandra. 2001. The Role of Market Size in the Formation of Jurisdictions. Review of Economic Studies 68(1): 83-108.

[14] Casella, Alessandra, and Jonathan S. Feinstein. 2002. Public Goods in Trade: On the Formation of Markets and Jurisdictions. International Economic Review 43(2): 437462.

[15] Che, Yi, Yi Lu, Justin R. Pierce, Peter K. Schott, and Zhigang Tao. 2016. Does Trade Liberalization with China Influence U.S. Elections? NBER Working Paper No. 22178.

[16] Colantone, Italo, and Piero Stanig. 2018a. Global Competition and Brexit. American Political Science Review 112 (2): 201-218.

[17] — 2018b. The Trade Origins of Economic Nationalism: Import Competition and Voting Behavior in Western Europe. American Journal of Political Science 62(4): 936953.

[18] Dauth, Wolfgang, Sebastian Findeisen, and Jens Suedekum. 2014. The Rise of the East and the Far East: German Labor Markets and Trade Integration. Journal of the European Economic Association 12(6): 1643-1675.

[19] Dippel, Christian, Robert Gold and Stephan Heblich. 2015. Globalization and Its (Dis-) Content: Trade Shocks and Voting Behavior. NBER Working Paper No. 21812.

[20] Epifani, Paolo, and Gino Gancia. 2008. The Skill Bias of World Trade. Economic Journal 118(530): 927-960.

[21] European Commission. 2006. Attitudes towards European Union Enlargement. Special Eurobarometer 255 .

[22] Feigenbaum, James J., and Andrew B. Hall. 2015. How Legislators Respond to Localized Economic Shocks: Evidence from Chinese Import Competition. Journal of Politics 77(4): 1012-1030.

[23] Freund, Caroline, and Emanuel Ornelas. 2010. Regional Trade Agreements. Annual Review of Economics 2(1): 139-166.

[24] Gancia, Gino, Giacomo Ponzetto, and Jaume Ventura. 2018. Globalization and Political Structure. NBER Working Paper No. 22046. 
[25] Grossman, Gene M. 2016. The Purpose of Trade Agreements. In Handbook of Commercial Policy, Vol. 1A, edited by Kyle Bagwell and Robert W. Staiger, 379-434. Amsterdam: Elsevier.

[26] Grossman, Gene M., and Elhanan Helpman. 2018. Identity Politics and Trade Policy. NBER Working Paper No. 25348.

[27] Grossman, Gene M., Phillip McCalman, and Robert W. Staiger. 2019. The "New" Economics of Trade Agreements: From Trade Liberalization to Regulatory Convergence? NBER Working Paper No. 26132.

[28] Harstad, Bård. 2006. Flexible Integration? Mandatory and Minimum Participation Rules. Scandinavian Journal of Economics 108(4): 683-702.

[29] Helpman, Elhanan, and Paul Krugman. 1985. Market Structure and Foreign Trade: Increasing Returns, Imperfect Competition, and the International Economy. Cambridge, MA: MIT Press.

[30] Jensen, J. Bradford, Dennis P. Quinn, and Stephen Weymouth. 2017. Winners and Losers in International Trade: The Effects on US Presidential Voting. International Organization 71(3): 423-457.

[31] Oates, Wallace E. 1972. Fiscal Federalism. New York, NY: Harcourt Brace Jovanovich.

[32] Maggi, Giovanni. 2014. International Trade Agreements. In Handbook of International Economics, Vol. 4, edited by Gita Gopinath, Elhanan Helpman and Kenneth Rogoff, 317-390. Amsterdam: Elsevier.

[33] — 2016. Issue Linkage. In Handbook of Commercial Policy, Vol. 1B, edited by Kyle Bagwell and Robert W. Staiger, 513-564. Amsterdam: Elsevier.

[34] Mayer, Thierry, Vincent Vicard, and Soledad Zignago. 2019. The Cost of Non-Europe, Revisited. Economic Policy 34(98): 145-199.

[35] Pastor, Lubos, and Pietro Veronesi. 2019. Inequality Aversion, Populism, and the Backlash Against Globalization. NBER Working Paper No. 24900. 